\title{
HACIA UNA EDICIÓN CRÍTICA DE SOR JUANA (SEGUNDA PARTE)
}

El presente artículo convierte en "primera parte" el que publiqué en la NRFH en 2003. Lo que me movió a escribir esa "primera parte" fue el estudio de las "variantes" de las ediciones antiguas de sor Juana (desde 1689 hasta 1725), puestas cómodamente a la vista de todos por Gabriela Eguía-Lis Ponce en sus "Apéndices" a la excelente edición facsimilar (México, 1995) de los tres tomos originales $(1689,1692,1700)$. Y lo que me ha movido a escribir esta segunda parte es la edición parcial publicada recientemente por Georgina Sabat de Rivers y Elias Rivers ${ }^{1}$ en un volumen que he leído con atención y lápiz en mano, teniendo como "trasfondo" la "primera parte". Si ésta hubiera aparecido uno o dos años antes, quizá les hubiera servido de algo a S\&R. Lo que ahora voy a decir es a menudo, inevitablemente, repetición de lo ya dicho; pero creo que más vale repetirme que remitir al lector a cada paso a la "primera parte", con página y renglón.

Aunque en la extensa Introducción de S\&R no hay "agua para mi molino" (o sea mi idea de lo que ha de ser una "edición crítica"), no me parece impertinencia comentar algunas de las cosas que allí he leído, comenzando con la biografía (pp. xiv-xxix).

${ }^{1}$ Emplearé estas abreviaturas:

MP: Alfonso Méndez Plancarte como editor de los tres primeros tomos de Obras completas de sor Juana, México, 1951-1955. Los números con que identifico los textos son siempre los que MP les pone.

S\&R: Georgina Sabat de Rivers y Elias Rivers (eds.), Sor.juana Inés de la Cruz, Poesía, teatro, pensamiento, lírica personal, lírica coral, teatro, prosa. Introd., ed. y notas de..., Espasa, Madrid, 2004 (Biblioteca de literatura unizersal); xcvi + 1624 pp. 
El padre de sor Juana recupera en esta biografía su verdadero apellido: no Asbaje, sino Asuaje. En cambio, el apellido de la madre está alterado: no es Ramírez de Santillana, sino de Cantillana? ${ }^{2}$.

En cuanto al año de nacimiento de sor Juana, S\&R se inclinan decididamente por 1651; yo sigo pensando, como MP (t. 1, p. liii), que sor Juana se quitó tres años al comunicarle el dato al padre Calleja, o sea que nació en $1648^{3}$. S\&R confian en los hallazgos de Augusto Vallejo, pero mientras éstos no se hayan editado en debida forma, no cambiaré yo de opinión, si bien reconozco que el asunto adhuc sub judice est. (Por lo demás, no tiene mucha importancia.)

Aproximadamente en 1660, dicen S\&R (p. Ixxxi), Juana Ramírez "se traslada a casa de sus tíos los Mata" y "aprende rápidamente el latín". Lo primero bien puede ser, pero lo segundo no. De la Carta al padre Núñez se deduce claramente que las clases que le dio Martín de Olivas a Juana Ramírez fueron muy tardías ${ }^{4}$.

${ }^{2}$ El apellido Cantillana consta no sólo en la Vida del padre Calleja, sino también en cierta declaración de un descendiente de Isabel llamado Bernardo Ramírez Cantillana (GuLlermo RAmírez EsPAÑa, La familia de sor Juana Inés de la Cruz, México, 1947, documento xxIx). "Isabel Ramírez de Çantilla$n a$ ", escribe MP citando a Calleja, pero lo que Calleja dice es Cantillana. No sé si el absurdo Çantillana se lo copió a NEMesio GarCía Naranjo, "Biografía de sor Juana Inés de la Cruz", Anales del Museo Nacional de México, $2^{\mathrm{a}}$ época, 3 (1906), p. 562. En todo caso, así pudo saltar de Cantillana a Santillanay de allí a Santillán, con lo cual Isabel Ramírez venía a quedar "posiblemente enlazada con diversas nobles familias", una de ellas la de la noble señora que fundó el convento de San Jerónimo (fantasía aceptada por S\&R: "Isabel Ramírez de Santillana..., probablemente descendiente de una familia relacionada con la fundadora de San Jerónimo"). Ya en otra ocasión he comentado esta manía "ennoblecedora" de Méndez Planearte. Es como la manía de emparentar a Juan Ruiz de Alarcón y Mendoza con el virrey Antonio de Mendoza y aun con don Iñigo López de Mendoza, marqués de Santillana. ¡Como si no fuera mayor mérito (mayor "nobleza"), en los dos casos, haber subido desde muy abajo! Que es lo cune sor Juana sentía: cf. el romance "Ilustre mecenas mío...", w. 9-16.

${ }^{3}$ Cf "Para leer la Fama y Obras pósthumas", NRFH, 29 (1980), p. 479, nota 114. En la Vida de Calleja se lee que sor Juana nació el viermes 12 de noviembre de 1651, a las 11 p.m. Pero ese día no cayó en viernes, sino en domingo. Tampoco en 1648 cayó en viernes, sino en jueves; pero 11 p.m. es ya casi media noche. Propongo, pues, esta solución: sor Juana nació en la noche interpuesta entre el jueves 12 y el viernes 13 de noviembre de 1648 . El acta en que se registra el bautismo de la "hija de la Iglesia" apadrinada por dos hermanos de Isabel Ramírez es de fecha 2 de diciembre de 1648: entre el día del nacimiento y el del bautizo han pasado, como es normal, unas pocas semanas.

${ }^{4}$ Cf. mi edición de la Carta, NRFH, 35 (1987), pp. 660-662: "Quando 
He aquí otro dato que pide rectificación: aproximadamente en 1665, según S\&R (ibid.), los virreyes marqueses de Mancera "invitan [a Juana] a ser miembro de la corte". No repiten lo que tantos han dicho: que fue invitada a ocupar el puesto de dama de honor, pero "miembro de la corte" es prácticamente lo mismo. Ahora bien, aunque Calleja hermosea un tanto este momento tan trascendental, lo que dice da a entender claramente que los parientes de Juana le consiguieron un puesto en la servidumbre del palacio virreinal (y no es de suponer que los virreyes se ocuparan personalmente de este asunto: de minimis non curat praetor). Sor Juana entró en palacio como criada, pero resultó ser una criada excepcional; los virreyes se fijaron en ella porque vieron "que acertaba, como por uso, en cuanto, sin mandárselo, obedecía”: como si ya tuviera, tan joven, el hábito que sólo la experiencia le da a una buena criada. En la p. xviii no dicen S\&R que los virreyes invitaran a Juana a ser "miembro de la corte", sino sólo que ellos "aceptarían, probablemente por sugerencia de la familia Mata, que Juana entrara en palacio"s.

En cuanto a la profesión religiosa, S\&R cometen (p. lxxix) un pequeño error: no fue "realizada en la Catedral", sino en San Jerónimo (en la catedral no se celebraban profesiones de monjas ni de frailes). Lo que dice el Libro de profesiones es que sor Juana hizo su profesión "en manos" de un canónigo que acudió al convento en representación de fray Payo, superior ex officio de todos los conventos femeninos.

En la p. xxiii dicen S\&R que "sor Juana escribió, al parecer a pedido de la marquesa de la Laguna, el tratado que tituló $\mathrm{El} \mathrm{ca-}$ racol". Pero no es así: lo que hizo la marquesa fue pedirle a la monja un tratado ya existente, que ella había escrito para utilidad de "sus carísimas hermanas", como dice Calleja. El romance "Después de estimar mi amor..." (MP, núm. 21) es respuesta al pedido de la marquesa: no le manda sor Juana El caracol por-

[entré en el convento], avía mui poco que yo tenía la dicha de conocer a V.R.”; y fue Núñez quien le pagó las clases de latín. Si éstas fueron tan pocas ("creo que no llegaron a veinte", dice ella en la Respuesta a sor Fïlotea), es porque Núñez "maduró y abrevió quanto pudo" la entrada en el convento (Oviedo, Vida de Núñez, p. 133).

${ }^{5}$ ¿Por qué probablemente? No hay para esto más documento que la Vida de Calleja, donde se lee que los "parientes" de Juana (que no pueden ser sino sus tíos María Ramírez y Juan de Mata, residentes en México) "la introdujeron en el palacio". - En nota al romance 36, S\&R suponen que lo escribiố sor Juana "cuando era «criada» en palacio". 
que está muy "informe" (indigno de pasar a la imprenta), pero, eso sí, se luce con el vocabulario musical que posee.

Finalmente, al llegar a los dos últimos años de vida de sor Juana (pp. xxvi-xxvii), S\&R dicen que no está bien hablar de "conversión", pues ¿acaso "dejó sor Juana de creer alguna vez?", a lo cual se puede responder que conversión no es sólo "paso del no creer al creer', sino, de manera general, 'mutación de una cosa en otra'; y el hecho (consignado no sólo por Calleja, sino también por Oviedo en la Vida de Núñez) es que en 1693 sor Juana "tomó otro camino, / dejó el que tenía". Como dice la Elegía de Calleja: "En los dos años últimos de vida / se alimentó de ayunos y asperezas". Ahora bien, según Elias Trabulse, La muerte de sor Juana, México, 1999, lo que sucedió es algo más complicado: entre abril de 1693 y febrero de 1694 -dice-, sor Juana estuvo "sujeta a un proceso episcopal conducido en secreto", y quedó condenada a "abjurar de sus errores, entregar sus bienes y biblioteca al arzobispo" y quedarse callada. A pesar de tan severa condena, siempre según Trabulse, sor Juana "rehizo su biblioteca y siguió escribiendo": en un registro de "lo que existía en su celda a la hora de su muerte" se mencionan 180 libros y 15 "legajos". Esto contradice a Calleja, según el cual la monja "no dejó en su celda más de solos tres libritos de devoción". S\&R mencionan la primera noticia, o sea el supuesto "proceso secreto" (p. lxxi, nota), pero ni la aceptan ni la rechazan, seguramente porque Trabulse no ha publicado los documentos pertinentes; aceptan, en cambio, la segunda, o sea lo de los libros y manuscritos "que se hallaron en la celda de sor Juana antes de morir". De este asunto ya me ocupé en 1999, pero como S\&R parecen no haberme leído ${ }^{6}$, resumiré lo que dije: Esta vez sí está publicado el documento pertinente, pero Trabulse no ha sabido interpretarlo. Se trata de una declaración escrita en 1843 por quien era a la sazón el capellán de San Jerónimo: dice haber consultado en el archivo del convento "un libro general de inventarios de los objetos que cada celda de las monjas tiene", una de ellas la de sor Juana. Pero el capellán no dice que ese inventario general se haya hecho "a la hora de la muerte" de sor Juana (de la cual dice que fue "abadesa [!!] de este convento"). De hecho, no da fecha alguna. Son los 180 libros y los 15 "legajos" los que nos dan la pista para la datación

${ }^{6}$ Me refiero a mi reseña del libro de Trabulse en $N R F H, 47$ (1999), pp. $443-445$. 
del documento: este inventario, uno de los incluidos en el "libro general", se hizo en los días en que sor Juana, aunque había escrito bastante -varios de los legajos serían de villancicos--, poseía aún muy pocos libros (los aprobados por el padre Núñez; ¡nada de literatura profana!); es un testimonio anterior a los anni mirabiles de la amistad con la condesa de Paredes.

El cuerpo del libro (1569 páginas) contiene una amplísima antología de obras de sor Juana. Pero eso - lo digo desde ahorano le quita vigencia a la edición de Obras completas de MP y A.G. Salceda. De lo que hay en el tomo 1 de esas Obras, S\&R han hecho seis supresiones, tres de ellas por buenas razones ${ }^{7}$ y las otras tres, según me parece, sin razón: los romances "Madre que haces chiquitos..." y "A vos, mexicana musa...", así como el soneto "En pensar que me quieres, Clori, he dado..." forman un todo con las respectivas respuestas de sor Juana; leer sólo las respuestas es leer la $\mathrm{mitad}^{8}$. Del tomo 4 sólo han omitido la comedia Amor es más laberinto. Los más "castigados" han sido los tomos 2 y 3: S\&R suprimen seis de las doce series de villancicos ${ }^{9}$ y nueve de las trece loas sueltas. A sabiendas de que todo antólogo tiene derecho a sus preferencias (y de que siempre hay $\mathrm{em}$ barras du choix etc.), yo le hubiera ofrecido al lector, en vez de una de las dos series de villancicos a la Asunción, la serie dedicada a San José, que es, para mí, una de las más interesantes; y también le hubiera ofrecido las 32 letras de San Bernardo, tan originales, tan rebosantes de ingenio y de primores métricos, $\tan$ representativas de la finura a que llegó sor Juana en esa clase peculiar de poesía religiosa.

Como para compensar las omisiones, S\&R incluyen tres cosas descubiertas en los últimos decenios: los Enigmas dedicados a las monjas portuguesas, el soneto "Érase un preste cara de tes-

${ }^{7}$ A saber, los núms. 133-134, muy arduos para el "culto lector" de nuestros deshumanizados tiempos, y el núm. 139, que es obra ajena. "Glosa erróneamente atribuida a Góngora”, dicen S\&R, pero no es así: la cuarteta que se dio a glosar, "Mientras él mira suspenso...", procede del romance "La que Persia vio en sus montes...", ése sí erróneamente atribuido a Góngora en la edición de Hoces y Córdoba; la glosa de la cuarteta es del poblano Felipe de Salaizes.

${ }^{8}$ Las tres piezas "ajenas" tienen tanto derecho a figurar en las obras de sor Juana como la carta de sor Filotea de la Cruz, ésta sí incluida en S\&R.

${ }^{9}$ Suprimen también, por supuesto, los muchos villancicos que MP creyó "atribuibles" a sor Juana sin más razón que porque le parecieron bonitos. 
tuz..." y la Carta al padre Núñez ${ }^{10}$. Según parece, estuvieron tentados a incluir también la Carta de Serafina de Cristo; si no la incluyeron fue "por no estar aclarada su autoría"ll.

S\&R hacen, "para mayor claridad, una nueva clasificación de la obra de sor Juana, basada en temas y en géneros": así "poesía de tema amoroso", "poesía civil y cortesana”, etc. Yo creo que la obra de sor Juana tiene la misma "claridad” con esta clasificación que con la ordenación métrica que hace MP: romances, redondillas, décimas, sonetos, etc. Tanto da lo uno como lo otro. S\&R hacen incluso subdivisiones: composiciones de "celos", de "ausencia", "de cumpleaños", "de retrato", etc. Repito: no hay sino respetar sus preferencias ${ }^{12}$; pero si se tratara de una edición crítica, pienso que lo sensato sería mantener el orden en que las obras se presentan en la Inundación castálida y en el Segundo volumen. En los libros de poesía de los siglos de oro era práctica común entreverar temas y metros diferentes, buena manera de hacer más variada y agradable la lectura; y es bien posible que sor Juana haya tenido que ver con la disposición de esos dos tomos.

Paso ahora a lo más importante, que es el texto que S\&R le ofrecen al lector. Es, en varios lugares, mejor que el ofrecido

${ }^{10}$ En la p. lxxi dicen S\&R que este título es invento mío, lo cual no es exacto: yo no hago sino respetar el que tiene en el manuscrito de Monterrey. (Por lo demás, es el título que ellos mismos le ponen al documento.) En cuanto al soneto "Érase un preste cara de testuz...", dicen S\&R en la nota respectiva que es "réplica de sor Juana" a un soneto de fray Luis Tineo, pero es al revés: fue el docto fraile quien le replicó a sor Juana (y también en este caso hubiera sido muy bueno incluir los dos sonetos, íntimamente trabados). En la p. xciv se lee que el mencionado soneto está "dirigido por sor Juana a Francisco de las Heras", lo cual, obviamente, es un simple lapsus.

${ }^{11}$ En Serafina y sor Juana (El Colegio de México, 1998), Martha Lilia Tenorio y yo aventuramos la hipótesis de que el autor fuese Castorena: los mismos versos pedestres, la misma prosa dominguera, la misma zalamería para con el obispo de Puebla; además, esa Carta es un elogio de sor Juana y una defensa de la Crisis contra el ataque del "Soldado", y sor Juana le agradeció a Castorena el "papel que discurrió en elogio y defensa" de ella. Eso, por supuesto, no es dejar "aclarada la autoría", de manera que si alguien presenta un candidato mejor (y no se diga si descubre un documento en que conste quién era Serafina), yo encantado, -y también, seguramente, Martha Lilia Tenorio. Pero estoy convencido de que la verdadera y poderosa razón para no incluir entre las obras de sor Juana esa dichosa Carta es otra: sea de quien sea, no es de ella. La mera posibilidad de que sor Juana sea la autora es ya un absurdo.

12 A causa de la "nueva clasificación" hay cuatro series de "Notas" entreveradas en el texto (comienzan respectivamente en las pp. 465, 673, 1335 y 1545). Esto, para mí, resulta francamente incómodo. 
por MP, pues éste, como ya observé en mi artículo de 2003, tiene el grave inconveniente de no basarse en las ediciones originales de los dos primeros tomos, sino en algunas de sus reediciones. He aquí dos ejemplos. En la Inundación castálida se lee, correctamente, "ni sangre se efunde humana" (19:47), pero la edición manejada por MP trae una errata, enfunde en vez de efunde, y él corrige (mal): infunde. En el Segundo volumen se lee, correctamente, "la adoración, más que el contacto, llega" (65:10), pero MP reproduce el texto de 1725: "más que el contacto, la adoración llega" (feísimo endecasílabo). En ambos casos restauran S\&R las lecciones originales. No siempre lo hacen. Tomo como ejemplo el romance-dedicatoria que se imprimió por primera vez en la $2^{\mathrm{a}}$ edición del primer tomo. Aquí se lee: "Esos versos, lector mío... / ni disculpártelos quiero...". MP imprime "Estos versos..." y "ni disputártelos quiero"; por su parte, S\&R restauran la lección "Esos versos..." (y hacen bien), pero mantienen la lección disputártelos (y creo que no hacen bien) ${ }^{13}$.

De hecho, gran parte de la edición de S\&R es reproducción de la de MP (y de Salceda). Para los villancicos de Santa Catarina, MP se basó en la edición suelta de Puebla, 1691, que tiene algunas erratas corregidas por sor Juana al enviarlos a España, donde aparecieron por primera vez en la $2^{2}$ edición del tomo 2 , Barcelona, 1693. MP imprime "mil cierzos conjuran" (316:17) y "descollante triunfante" (321:14); las lecciones correctas son obviamente las de la edición barcelonesa: "mil cierzos se conjuran", "descollaste triunfante"; y S\&R, confiados en MP, copian ambos errores. Un caso aún más claro es el de la Crisis del sermón de Vieira. Salceda se basa en la edición poblana de 1690, donde hay, además de erratas, gran cantidad de pasajes en que sor Juana hizo enmiendas (incluyendo adiciones y supresiones) ${ }^{14}$. Para mí es claro que la versión que ella quiso darnos de

${ }^{13}$ Dicen en la nota respectiva: "En'vez de disculpártelos, que se encuentra en el original, aceptamos la enmienda disputártelos, que se encuentra en ediciones posteriores y en MP". Yo no la llamo "enmienda", sino error: no veo de qué manera podría sor Juana disputarle al lector los versos que le está ofreciendo en el volumen; disculpárselos, sí que puede, pero no lo va a hacer: 'No voy a suplicarte [como a veces se hace] que perdones los defectos de mis versos; así son, y ya'. Esta aclaración tiene que haber sido muy importante para ella, puesto que la desarrolla minuciosamente a partir del v. 33: "Bien pudiera yo decirte, / por disculpa...", etc.

${ }^{14}$ Cf. mi artículo "Una Defensa del padre Vieira...", NRFH, 53 (2005), p. 81, nota 22, y pp. 87-88. 
ese importante escrito, su texto "definitivo", es el que le mandó a don Juan de Orúe para que lo imprimiera en el Segundo volumen (1692), donde figura, además, con el título que ella quiso darle, Crisis sobre un sermón... etc., y no con el rimbombante de Carta atenagórica que el obispo de Puebla tuvo a bien colgarle. S\&R reproducen el título y el texto que imprimió Salceda. Una edición crítica debiera presentar el de 1692, con notas que hagan ver los cambios efectuados (como las notas con que Robert Jammes, en su edición de las Soledades, nos hace ver el estado "primerizo" de varios pasajes).

Fue seguramente en 1691 cuando sor Juana le mandó a don Juan de Orúe y Arbieto los manuscritos de las obras que, dedicadas a él, se estamparon en el Segundo volumen (Sevilla, 1692). Al final de la dedicatoria le dice: "Espero con el tiempo ofrecerle otras, si no más primorosas, no tan incultas". Años después, Castorena y Ursúa dice en el Prólogo de las Obras pósthumas (Madrid, 1700) que "muchos discretos papeles" de sor Juana "se perdieron", y añade, con poca lógica: "algunos de éstos discurro ser los que [ella] ofreció en la dedicatoria de su segundo tomo... a don Juan de Orúe..., pues este caballero me afirmó tenerlos en la Andalucía". En "Para leer la Fama...", NRFH, 29 (1980), nota 24, supuse que Orúe conservaba en Sevilla los originales del Segundo volumen; pero quizá tenga razón MP al entender (Obras completas, t. 1, p. xlv) que, "a más de lo ya impreso", Orúe poseía algunos inéditos. En un pasaje anterior dice Castorena: "Esperaba también recoger otros manuscritos de la Poetisa, y éste, con sus originales, colocarlos en el estante que dorando ocupan sus dos antecedentes en... la gran librería de religiosos jerónimos" del Escorial. Seguro de que los dos primeros tomos están ya en el Escorial, "dorando" el anaquel en que fueron colocados, se promete Castorena llevarles éste (o sea el tercero) a los jerónimos, junto con los originales, o sea los manuscritos que se han impreso en la Fama. Sería estupendo que un día se hallaran los papeles que conservaba Orúe en la Andalucía y/o los que Castorena llevó (si es que los llevó de veras) a la biblioteca del Escorial. Seguramente no serán autógrafos: en el romance-prólogo "Esos versos, lector mío...", habla sor Juana de "la prisa de los traslados", o sea las copias "de diversas letras", algunas de las cuales ha tenido que corregir a fondo, pues parecían obra de "muchachos". Pero, aunque no se trate de autógrafos, serían de valor inestimable para una edición crítica. 
Desgraciadamente, lo único que tenemos son los libros impresos, y es un hecho que en todas las ediciones antiguas hay erratas de imprenta. La primera tarea crítica consiste en eliminarlas. Para algunas, la corrección es obvia ('sale al encuentro'). Ningún editor va a imprimir "te la doy" en la Loa a la Reina, v. 113, pues el pronombre debe corresponder a consentimiento; cualquiera puede descubrir las faltas de concordancia entre dos verbos que deben estar en el mismo modo; cualquiera puede notar que en tal verso hay una sílaba de menos, o una de más. Etc. Pero no todas las erratas son "obvias": algunas se esconden al lado del camino, en la maleza; el que las desembosque, buen editor será. Varios de los hallazgos de MP son dignos de Sherlock Holmes. Él es el fundador de la crítica textual sorjuanina. Y la fundó con solidez.

Para mostrar gráficamente la "situación" (el "estado de cosas") desde el punto de vista de una ideal edición crítica, presento una comparación detallada (no exhaustiva) entre lo que hizo MP y lo que hacen $S \& R$, dividiendo la materia en cuatro listas ${ }^{15}$. En la primera recojo las enmiendas justas que hace MP a los textos originales, y que S\&R hacen también: son enmiendas "de sentido común". En la segunda recojo enmiendas igualmente justas de MP, pero rechazadas por S\&R. En la tercera recojo enmiendas "desacertadas" (innecesarias, y a veces hasta erróneas) que $S \& R$ tienen razón en no aceptar. Y en la cuarta, lecciones igualmente "desacertadas" de MP, pero que S\&R sí aceptan.

\section{LISTA I. ENMIENDAS EN QUE S\&R COINCIDEN CON MP ${ }^{16}$} $(2: 142)$;

1. "Aprendamos a ignorar, / pensamientos": Pensamiento

${ }^{15}$ En general, omito en esta comparación las discrepancias en cuanto al uso de los pronombres de $3^{\text {a }}$ persona $(l e, l o, l a)$ y de la preposición $a$ de complemento directo. MP tiende a la uniformación, y sustituye usos de las ediciones originales por usos modernos. Así "le intitulé Caracol" > "lo intitulé" (21:132); "aunque cualquiera la salga > "le salga" (36:60); "que aun hoy $e l$ mundo asombra" > "al mundo asombra" (157:8); "turbando a los ojos" > "turbando los ojos" (loa de El mártir del Sacramento, 181), etc. Y S\&R suelen seguir el ejemplo de MP. Yo, como digo en el artículo de 2003, pp. 506-508, creo que no hay razón para "corregir" esos usos (o esas indecisiones), que eran normales.

${ }^{16}$ Pongo siempre primero el texto original y en seguida el de MP (con el número que tiene en su edición). - S\&R declaran en algunos casos que 
2. "Si el restituirse no puede": "Si él resistirse no puede" $(4.105)$;

3. "se distinguen / el objeto": "se distingue" (4:133);

4. "nuestras dos vidas..., / y Láquesis, al formarlos, / de un solo copo los hile": "al formarlas", "las hile" (5:67-68);

5. "se tienen por bien empleados / privilegios de presentes / los años que ya pasaron": "tienen, por bien empleados, / privilegios..." (13:14);

6. "Mas ya que estáis cansada": "que estaréis" (20:53);

7. "la voz... / al tiempo que es preferida": proferida (21:78);

8. "que den sucesión dichosa": "que deis" (25:149)17.

9. "èl, y à Elesponto surcó": "el Helesponto surcó” (26:31);

10. "se corta / a aquel cuello": "a aquél el cuello" (31:39);

11. "que haya quien / le pese": "que haya a quien" (33:7);

12. "libre parece que nacen": libres (37:90);

13. "si cuando os miro más alto / tanto estáis de mí más lejos": "si cuanto os miro" (39:23);

14. África: Ática (39:151);

15. "[Bien quisiera que esta perla] excediera... a la que.../ o aquella que...": "o $a$ aquella que..." (40:45);

16. "hallé al fin que los pintores / eran como los quereres": "que los pintares..." (43:71);

17. "Como no sabéis quién sois": "quién soy" (44:65);

18. "los dos Paliscos": "los dos Palieos" (46:58);

19. "impedida el aliento": "impelido el aliento" (47:21);

20. "que fúnebres o festivos / ...han mostrado en sus escritos": "se han mostrado" (50:80);

21. "tubernaria scena": "tabernaria escena" (50:119);

22. "Si la Combinatoria... / se yerra": "no yerra" (50:184);

23. "la Abeja tiene / tan íntima dependencia / ...con la Abeja": "con la Rosa" (53:27);

24. "La Abeja paga el rocío / de que la Rosa la engendra, / y ella vuelve a retornarle / con lo mismo que la engendra": "con lo mismo que la alienta" (53:40);

adoptan las enmiendas de MP; pero en otros, por ejemplo en los núms. 14 y 18 de la lista que sigue, no anotan nada. Claro que no es imposible que ellos hayan llegado por cuenta propia a las lecciones Ática y Paticos.

17 S\&R intentan una defensa de la lección den, pero "adoptamos la lectura de MP". Parece que no consultaron la fe de erratas de la Inundación castálida: "que den, di que deis". 
25. "la que $a$ italiana / cultura lucida / junta la española": "la que a la italiana" (67:9);

26. "de sus bellos ojos": "de tus bellos ojos" (70:63);

27. "Agrísima Gila, / que en lugar de dar / confites al gusto, / dentera les das": "dentera le das" (72:4);

28. "Y si alguna vez sin susto / consigo tal posesión, / que cualquier leve ocasión / me malogra todo el gusto": “...tal posesión, / cualquiera leve ocasión / me malogra..." (84:23);

29. "se abalanza... / y después... / tomo de mí otra venganza": "toma de mí" (84:68);

30. "si aborrezco a quien me quiere, / ¿qué haré con quien aborrezco?": "...con quien me aborrece?" (85:24);

31. "ya, si librarme confio...": "y asílibrarme confío" (99:15);

32. "te da de $t u$ amor la palma": "de su amor" (102:6);

33. "tuvo ser": "tuve ser" (102:19);

34. "cuanto avista": "cuanto a Vesta" (111:15);

35. "que no es querer la medida / pedírtela regulada": "que no es quererla medida" (122:33);

36. "dulce ficción por quien penoso vivo": "por quien penosa vivo" (165:4);

37. "que infama $e l$ hierro al escorpión herido": "que infama al hierro el escorpión herido" (171:3);

38. "incapaz de conocerse": "de conocerte" (182:6);

39. "no es porque en la materia hay más nobleza": "hay más firmeza" (183:3) [cf. el v. 6 en el número siguiente];

40. "aquel apetito de mudarse, / la sacia de la forma la nobleza": "lo sacia" (183:6);

41. "y el que fin fue del círculo primero": "y que el fin fue..." (193:7);

42. "que si ellos dientes son": "que si ellas [las perlas]..." (214:70);

43. "téngansela en su palma / y haga lo que quisiere... / Vénguense del trabajo con morderlo": téngasela, vénguese (214: $114,118)$;

44. "las partes... ignorantes": integrantes (Sueño, v. 492);

45. "para que del mortífero veneno... / la confección hieieron provechosa": hicieran (Sueño, v. 536);

46. "en la mitad del globo que ha dejado / el sol desamparado": desamparada (Sueño, v. 964);

47. "la gloria que tú das, / y así no espere jamás": "no esperes jamás" (217:38);

48. "no tuvo para la alteza": "no tuvo para élalteza" (261:13); 
49. "alabarle / podemos serlo": "podemos sólo" (261:39);

50. "ríos, arroyos, fuentes, mares": "los ríos, los arroyos, fuentes, mares" (263:18);

51. "tus penas atroces / oigan tus querellas": "oigan, y tus querellas" (263:29);

52. "esta insaciable fatiga? / $E l$ hambre sacra del oro...": "fatiga / del hambre..." (Loa al Rey-11, 128-129);

53. "Luego no eres tu esencia?": "Luego no eres tú su esencia" (sin interrogación) (ibid., 217);

54. "Yo soy de la misma": "Y yo soy..." (ibid., 316);

55. [Supresión de dos versos al final del parlamento de la Majestad] (ibid., 370);

56. "y por aquéllos alcanza... / y pueda elevarse": "y por aquéllos alcance" (Loa a la Reina, 21);

57. "da tú tu consentimiento... / -Ya te la doy": "te lo doy" (ibid., 113);

58. "la invocación empiece...; / empiece la Memoria": "empiécela la Memoria" (ibid., 149);

59. "AAh del Tiempo Presente, / flexible instante...!": "fluxible instante" (ibid., 156);

60. "tu imperio solamente / le puede ejecutar en lo Presente": "se puede ejecutar" (ibid., 232);

61. "Sale el Tiempo Futuro con una brújula y un tintero": "con un espejo" (ibid., acotación al v. 239);

62. "él podrá comenzar": "él lo podrá comenzar" (ibid., 255);

63. "la Edad de Oro, pues es con su asistencia": "pues lo es con su asistencia" (ibid., 266);

64. "aunque el premio se impida": "se me impida" (ibid., 331);

65. "pues reina más que su imperio"; "más que en su imperio" (ibid., 339);

66. "y pues es vencimiento": "y pues es el vencimiento" (ibid., 348);

67. "y una razón de belleza..." / "y una, a razón de belleza..." (ibid., 352);

68. "ayude su aclamación": "ayude $a$ su aclamación" (Loa en las huertas, 32);

69. "quieres gozar": "quiere gozar" (ibid., 147);

70. conceptos: concentos (ibid., 201);

71. "y pues mi amor servirle no rehúsa": servirte (Loa a fray Diego Velázquez de la Cadena, 153);

72. "La $C . . . /$ con que su nombre empieza": "mi nombre" (ibid., 307); 
73. "Yo E, que el Entendimiento...": "Yo la E..." (ibid., 312);

74. "Y los dos Diegos": "Y a los dos Diegos" (ibid., 421);

75. "Y aqueste noble auditorio": "Y a aqueste" (ibid., 437);

76. "la Nobleza": "Nobleza" (ibid., 475);

77. "a su vulto sirva": "a su culto sirva" (loa para El divino Narciso, 26);

78. "Y con pompa festiva": "Y en pompa festiva" (ibid., 88) 18;

79. "a mi Religión": "a la Religión" (ibid., 132).

80. "plantas y flores": "fuentes y flores" (El divino Narciso, 9) 19;

81. "y es natural que lo teman": "que la teman" (ibid., 300);

82. "que es el efecto": "que es el afecto" (ibid., 316);

83. "elnúmero": "al número" (ibid., 557);

84. misteriosas: misteriosa (ibid., 587);

85. "y en elevada eminencia / de esta montaña"; "y en la elevada eminencia" (ibid., 672);

86. traiga: atraiga (ibid., 1214 [1124] $)^{20}$;

87. "Mira que soberano / soy, y que no hay fuerte": "y que no hay más fuerte" (1312 [1222] $)^{21}$;

88. "mi pena... / me sujeté a padecer": "me sujetó" (ibid., 1577 [1487]);

89. "De la fuerza del llanto / mi rostro se enternece": "mi rostro se entumece" (ibid., 1895 [1805]) $)^{22}$;

90. ayáis: vayáis (loa para El mártir del Sacramento, 21);

91. "que oigáis": "que me oigáis" (ibid., 195);

92. "impresos en el alma... / las especies": impresas (El mártir del Sacramento, 221);

93. "OÓiganlo! ¡Atiéndanlo!" (ibid., 993 y 1008, adiciones de MP por razones de simetría);

${ }^{18}$ La enmienda de MP se debe a razones de simetría: se trata de un estribillo que dice "Y en pompa festiva...", salvo aquí y en el v. 182.

${ }^{19}$ Esta enmienda está en el mismo caso que la del núm. 78: sólo en este verso y en el 158 se lee plantas en vez de fuentes.

${ }^{20}$ La ed. de 1691 dice: "nos sentaremos en tanto / que llega, que el que la atraiga"; en 1692 se corrige el la: "que él llega, que el que le traiga"; en la ed. de 1709 (que es la manejada por MP) se lee "que llega, que la traiga". -MP numera de 10 en 10 los versos; pero el número que sigue a 900 es 1000 , en vez de 910 . La numeración de $S \& R$ es correcta; pero como la edición que todo el mundo maneja es la de MP, sigo su equivocada numeración y pongo entre corchetes la de S\&R.

${ }^{21}$ Se repite aquí lo comentado en la nota anterior: en 1691 se lee "soy, que no hay más fuerte" (verso cojo), y en 1692: "soy, y que no hay fuerte" (también cojo). En los dos casos corrige 1692 una errata y mete otra.

22 1691: "se me entumece"; 1692: "se enternece"; 1709: "se entumece". 
94. Theudio: Teudis (ibid., 1029);

95. "que gobierna eficaz, suprema, aunque suave": "que gobierna suprema, aunque süave" (ibid., 1158) ${ }^{23}$;

96. "el séquito... que él ha seguido": "que lo ha seguido" (ibid., 1166);

97. " $h a$ sido... las que más / llegan a resplandecer": "han sido" (ibid., 1321);

98. "el curso de sucesos / ...lugar no daban / a esperar...": "lugar no daba" (ibid., 1597);

99. "Estas razones de estado / y estos motivos de afectos": "motivos de afecto" (ibid., 1662);

100. "Ya salgo": "Yo saigo" (ibid., 1787);

101. "a argüirme de misterio": "del misterio" (se refiere al bautismo) (ibid., 1895);

102. "Al nuevo Sol de la Fe... / la Ley Natural saluda / como suele $e l$ sol alalba": "como suele $a l$ sol $e l$ alba" (loa para El cetro de José, 4);

103. "tú como la parte, y yo / como el todo que le abraza": "que la abraza" (ibid., 44);

104. "se debe mejor ofrenda... / y si ahora al verdadero / Dios quieren sacrificarlas": sacrificarla (ibid., 298);

105. "el hacer": "el ser" (El cetro de José, 224) ${ }^{24}$

106. "y otra vez vuelve el Pan a dar honores / a mis tristes temores": "a dar horrores" (lo dice Lucero, o sea el Demonio) (ibid., 272);

107. "si las desvanece un sueño, / si una aprehensión las quita": "si los desvanece un sueño / y si una aprensión los quita" (ibid., 526-527) ${ }^{25}$;

108. severas: severos (se refiere a rigores) (ibid., 544);

109. "su intención": "tu intención" (ibid., 787);

110. "El que..., / el que... / llegad a adorar todos": "Al que..., al que..." (ibid., 802 y 806);

${ }^{23}$ La ed. original (1692) dice "que gobierna eficaz, suprema, aunque suave", verso de trece sílabas; la $2^{\text {a }}$ ed. (1693) corrige la hipermetría suprimiendo eficaz. Yo no vacilaría en suprimir mejor suprema: "que gobierna efi$c a z$, aunque süave" tiene sentido más pleno.

24 Abraham le dice a Dios: "Señor, si sin hijos muero, / ¿qué bien me puedes hacer, / si al fin será éste el hacer / mi criado mi heredero?", lo cual se entiende muy bien; la razón de la enmienda de MP es evitar la repetición de hacer, descuido quizá del tipógrafo.

${ }^{25}$ La enmienda las:los se impone (se refiere a "timbres" y "blasones"), pero la de aprehensión no tanto: bien podría medirse como tetrasílabo. 
111. "es repetir lo sabido / a quien escucha y quien habla": "a quien escucha, quien habla" (ibid., 1054);

112. "¿Qué enigmas, cielos, son éstas?": "son éstos" (ibid., $1183)^{26}$;

113. "no temas, joben": "No temas, Jacob" (ibid., 1342);

114. "el que del mundo": "que del mundo" (ibid., 1391)27;

115. "a todos sus hermanos preferido": preterido (ibid., 1445);

116. sustentaron: sustentan (ibid., 1666).

\section{Lista II. ENMIENDAS ACERTADAS DE MP RECHAZADAS POR S\&R}

1. "Si es causa amor productivo / de diversidad de afectos...": "Si es causa amor productiva..." (3:1) ${ }^{28}$;

2. "viva tu nombre y con él / se extienda al común provecho": "y con él / se extienda el común provecho" (3:336);

3. "No hagas que un amor dichoso / se vuelva en afecto triste": "se vuelva en efecto triste" (5:58);

4. "que tan gloriosa desgracia / más causa corrió que miedo": "más causa ánimo que miedo" (19:4) ${ }^{29}$;

${ }^{26}$ Podría salvarse éstas, pues se decía también la enigma; pero más adelante (v. 1231) enigma es claramente voz masculina.

${ }^{27}$ Dice Lucero acerca del José que "no es José" (sino figura de Cristo): "el que teme / mi Soberbia $e l$ que del mundo / el daño antiguo remedie", o sea: 'Teme mi Soberbia (=temo yo) el que éste sea el redentor del mundo' (con un $e l$ sustantivador de la oración subordinada); pero quizá hizo bien MP al enmendar: 'temo que éste sea...'.

${ }^{28}$ S\&R mantienen el productivo de la ed. original, a pesar de haberse corregido en las eds. subsiguientes. Su argumento no me convence. Calificar al amor de "productivo" es redundancia (todo amor es productivo; un amor "desactivado", que no produce afectos, ya no es amor). La frase "Si amor es causa productiva de afectos muy diversos" es impecable. Cf. "causa productiva" en el Sueño, v. 623. El modesto hipérbaton "Si es causa amor productiva" es como el de "Si al imán de tus gracias atractivo".

${ }^{29}$ S\&R defienden la palabra corrió. Dicen que así se lee "en todas las ediciones antiguas" (argumento inválido: en todas las eds. antiguas se lee sois y aborrezco, y sin embargo ellos corrigen soy y me aborrece. cf. Lista I, núms. 17 y 30 ). Dicen también que aquí el significado de corrió es 'extendió'; pero lo que entonces leemos es: "tan gloriosa desgracia extendió causa, pero sobre todo extendió miedo", lo cual no tiene sentido. El corrióes indefendible. La enmienda de MP, propuesta con mucha timidez, le da un significado pleno a toda la cuarteta: el atrevimiento del pincel ha acabado en fracaso (no ha conseguido retratar la hermosura de Filis); es como el atrevimiento de Ícaro o de Faetonte; pero su fracaso, como dice sor Juana (Sueño, 805-808), "alas engendra a repetido vuelo / del ánimo ambicioso". (Este argumento se le escapó a MP.) 
5. "grande, soberano excelso": "grande, soberano exceso" $(19: 174)$;

6. "cantando aquellas anàdes": "cantando aquellas tres ánades" $(26: 43)^{30}$;

7. "dale con tus ajos luces, / al Oriente con tu boca": "dale... / el Oriente con tu boca" (31:54);

8. "más que ellos": ellas (más que las pandectas) (38:123);

9. "el Tiempo flexible": fluxible (74:66) $)^{31}$;

10. "¡Oh, cuán loco llegué a verme / en tus dichosos amores...!": "¡Oh, cuán loca...!” (91:25) ${ }^{32}$;

11. "podrás... / decir que eres imposible, / pero no que no eres mío": "que eres impasible" (103:79) 33 ;

12. "El que a las prensas se inclina / sin influjo celestial...": "El que a las prendas..." (104:51) ${ }^{34}$;

13. "como hace huir la sangre allá en el pecho, / vaporiza en ardores por la vista": "como hace hervir la sangre..." (177:7) ${ }^{35}$;

30 "Para dezir que uno va caminando alegremente, sin que sienta el trabdjo, dezimos que va cantando Tres ánades, madre" (CovarrubIas, s. v. ánade); "Cantando las tres ánades, madre, dícese denotando facilidad en hacer algo...", etc. (Correas, Vocabulario de refranes..., ed. L. Combet, 2000, s. v. cantando). Tal vez en la copia manuscrita que llegó a manos del impresor faltaba el tres, y él restauró el octosílabo imprimiendo anàdes (palabra inexistente).

31 "Mantenemos flexible por su sentido de 'alargarse", dicen S\&R. Pero flexible no es 'que se alarga', sino 'que se dobla fácilmente' (en oposición a rigido). El adjetivo fluxible (¿inventado por sor Juana a partir de fluxus?), dicho del tiempo, o del agua (los "cristales fluxibles de Aganipe", 48:18), significa 'que fluye'. No veo por qué S\&R lo rechazan aquí y lo aceptan en un lugar análogo (supra, Lista I, núm. 59). Sor Juana distingue entre fluxible y flexible. "fluxible plata" del mar (Neptuno, "Explicación del arco", v. 73), "flexible círculo" de las virtudes de Neptuno, o del marqués de la Laguna (ibid., v. 92).

32 "Sor Juana utiliza el masculino o el femenino según convenga", dicen S\&R. Muy cierto. Y aquí lo que conviene es el femenino (cf. vv. 50-52). El cambio loco:loca es como el de penoso:penosa, que S\&R sí aceptan (Lista I, núm. 36).

33 "En las ediciones antiguas aparece siempre imposible", dicen S\&R, y es verdad: la errata de la ed. original se perpetuó. El adjetivo impasible, al final del romance, sintetiza todo lo dicho: que el retrato es ciego y mudo, insensible, imperturbable.

${ }^{34}$ La lección prensas es indefendible. Desde el principio de estas décimas distingue sor Juana entre dos clases de amor: "uno nace de elección / y otro de influjo imperioso"; hay quienes se inclinan a las prendas (belleza, etc.: amor de elección), y quienes son inclinados a amar por la fuerza de los astros.

35 La enmienda hervir es decisiva para el sentido. Sor Juana explica "fisiológicamente" las lágrimas: son vapores exhalados por la sangre que hier- 
14. olvidarte: agraviarte $(180: 7)^{36}$;

15. "la hermosa luz que a un tiempo concediste": "hermosa luz que un tiempo concediste" (189:4) ${ }^{37}$;

16. "la luz... / todo está en la ceniza venerada": "toda está..." (190:7);

17. "todos estos males / tienen consuelo..., / y los más son iguales / solicitan o animan la venganza": "y los más sin iguales..." (213:45);

18. "Empiezo por la diestra...; / pues no le queda en fuga la siniestra": "no le queda en zaga..." (214: 341) $)^{38}$;

19. "[De los rayos de sol la armadura], de las estrellas y el yelmo, / los botines de la luna": "de las estrellas el yelmo" (222:14);

20. "pues a él se le concede / hacer lo que Cristo hacía": "pues a él se le concede / como heredero, este día..." (234:19);

21. "Pedro goza tal grandeza / en que a Cristo parecía": "Pedro goza tal grandeza / que a Cristo solo venía" (234:26) ${ }^{39}$;

22. "sube sobre el firmamento": suba (273:44; cf. v. 47, pueda);

23. "hasta que Diosoquiera": "hasta que Dios quiera" (274:101) ${ }^{40}$;

ve en el corazón. (Cf. la explicación "fisiológica" de los suspiros en Garcilaso, soneto "De aquella vista pura y excelente...")

${ }^{36}$ Enmienda indispensable. La ley (dura lex) de los sonetos hechos "por los mismos consonantes" exige agraviarte en el v. 7 de los dos sonetos (180y 181). La ley prohibe también la repetición de rimas, y el soneto 180 tiene ya olvidarte en el v. 2. Cf. la Lista I, núm. 39, en que S\&R síremedian la repetición de una rima.

37 Un tiempo es locución adverbial, equivalente a otrora (Góngora, Soledad I, 883-884: "al sonoro / son de la ninfa un tiempo, ahora caña"). Los ojos de Laura no le concedieron su luz "a un tiempo"; se la concedieron al mundo mientras ella vivió. -MP suprime el artículo la con que comienza el verso, lo cual parece accidental (involuntario).

38 Dicen S\&R, aduciendo el Dicc. Aut., que "no le queda en fuga" significa 'no le queda en menos'; pero yo no encuentro tal cosa en el Dicc. Aut. La errata en fuga por en çaga es muy comprensible.

${ }^{39}$ S\&R dicen que MP cambió lo que se lee "en todas las ediciones antiguas", pero no dicen por quélo hizo: se trata, dice él, de "correcciones autógrafas de sor Juana" en un ejemplar de la edición suelta de 1677. No hay razón para rechazar tales enmiendas, pues él conocía ciertamente la letra de sor Juana. Pero hay que reconocer que la primera "corrección" nos deja sin saber qué cosa "se le concede" a san Pedro Nolasco, y que la segunda no es gran mejora.

40 Es verdad que el imitador del lenguaje del "negro camotero" dice una vez Dioso (v. 76), pero también dice Dios (v. 96). El heptasílabo "hasta que Dioso quiera" rechina en un romancillo hexasilábico. La enmienda de MP tiene mucha razón de ser. 
24. "[No hay miserable (cautivo, pobre, enfermo, etc.) que no padezca] del deseo de vivir / aquella innata caricia": "aquella innata codicia" (Loa al Rey-II, 46) ${ }^{41}$;

25. [La Vida ha dicho que "el vivir es en el hombre / lo primero", y la Majestad replica:] "No sufro / el pasar por que me pidas / que eres esencia en el hombre": "que me digas / que eres esencia” (ibid., 190) (es la réplica justa);

26. [Acotación:] Pomona: Vertumno (Loa en las huertas, 181) 42;

27. [Habla la Naturaleza:] "la mesma / obra que hago en vana especie / en un individuo hiciera": "la mesma / obra que hago en una especie [puedo hacerla en un individuo]" (Loa a fray Diego, 37);

28. [Sigue hablando la Naturaleza:] "Por mí, adornados de escamas, / y por mí, armados de testas, / los peces el mar habitan, / moran el monte las fieras": "y por mí, armadas las testas..." (ibid., 44) ${ }^{43}$.

\section{LiSTA III. LECCIONES DESACERTADAS DE MP RECHAZADAS POR S\&R}

1. "Decir que éste no es cuidado": "Decir que esto..." (3:141);

2. modestia: molestia $(3: 207)$;

3. nube: nieve (3:267);

${ }^{41}$ Una caricia no se padece; lo que se padece es ese torturante e insaciable apetito (=codicia) que es el deseo de seguir viviendo (cupiditas vivendi). Cudicioso es 'el que dessea algo'; se puede tener codicia "en el trabajar" o en el "hazer cada uno su hazienda" (Covarkubias, s. v. codiciary s.v. cudicia). Cf. el codiciosa de fray Luis, "Qué descansada vida...," v. 46.

${ }^{42}$ El texto de esta Loa en la Inundación castálida abunda en erratas, varias de ellas corregidas en la ed. del t. 1 de Valencia, 1709. Pero en ésta no se corrigen las acotaciones erróneas. Una de ellas es la enmendada por MP: el parlamento de los w. 181-185 le pertenece a Pomona, no a Vertumno. Es extraño que S\&R no acepten esta enmienda, cuando aceptan otras (vv. 185, 187, 190, 202 y 316). -Si se sigue con atención el decurso del pleito de Vertumno/Pomona y Céfiro/Flora, se verá (creo yo) que "Pues al duelo volvamos" (185) no le pertenece a Céfiro, sino a Flora, y que no es Flora, sino Vertumno y Céfiro, quienes dicen, al unísono, "Volvamos, pues es tan nuestro" (v. 187).

${ }^{43}$ Los versos impares de esta cuarteta se refieren a los peces, y los pares a las fieras; pero "armados de testas" (como se lee en la Inundación castálida) es incongruente en cuanto a la gramática (fieras armados) y en cuanto al sentido (¿cómo puede un animal estar "armado de testas"?). La corrección de MP, que da un gongorino ablativo absoluto, es intachable: las testas de las fieras están armadas (colmillos, cuernos). 
4. la suerte: las suertes (4:62);

5. "que las concilian los astros / o la engendran perfecciones": "que lo concilian... / o lo engendran..." (4:119-120) ${ }^{44}$;

6. "ejemplos mirando tantos": "registrando ejemplos tantos" $(7: 34)^{45}$

7. ofendiendo: ofendido (7:103);

8. "ya os asesto el memorial": "yo os asesto..." (11:31). (E1 yo de MP bien puede ser errata de imprenta.)

9. "todo temor los sentidos, / todo confusión el alma": "todos temor los sentidos, / toda confusión el alma" (11:58-59);

10. "lo que a espacio he cometido": "lo que espacio..." (11:62);

11. "que ella solamente suple...": "que allí.." (11:107);

12. movió: me dio (11:143);

13. "que os tengo ya referido": referidos (11:164);

14. "negocios más precisos": "tan precisos" (11:202);

15. mandatos: mandados (11:208);

16. exempciones [o sea exenciones]: excepciones (13:23);

17. "[estoy] de dome a Dios": "de doyme a Dios" (14:72);

18. transmutarse: transformarse (17:59);

19. "ese obsequio": "este obsequio" (18:27);

20. "ni sangre se efunde humana": "se infunde" (19:47);

21. "pasarse por la cartilla": pastarse (24:63);

22. "de que lo máximo crezca": "de que el Mejicano crezca" $(24: 88)^{46}$;

23. "Ya habéis experimentado... / florida a la primavera, / al estío macilento, / con su sazón al otoño / y con su escarcha el invierno": "florida la primavera, / el estío..., / el otoño... / el invierno" (25:101-104) ${ }^{47}$;

24. "es imposible saberlo, / luego también es decirse": "luego también lo es decirse" (30:39);

25. "por hacer una lisonja": "para hacer..." (31:20);

${ }^{44}$ Los pronombres las y la se refieren (con quiasmo) a causas y a correspondencia. Las enmiendas de MP hacen ciertamente más cómoda la lectura, pero no se imponen.

45 No pocos de los cambios erróneos (o innecesarios) de esta lista se deben a que MP no manejó las primeras ediciones de los tomos 1 y 2, sino sólo reediciones.

${ }^{46}$ La edición del t. 1 manejada por MP es la de 1709 (o más bien la de 1725), donde en vez de lo máximo se lee lo mexicano (!).

${ }^{47}$ En vez de homologar los tres primeros versos con el cuarto, MP hubiera podido homologar mejor el cuarto ("al invierno") con los otros tres. 
26. "es en mígusto, y es deuda": "es mi gusto y es mi deuda" (33:2). (Pero en S\&R falta el acento de mí.)

27. "Y cuantos el dulce lotos...": "Y a cuántos el dulce lotos..." $(37: 97)^{48}$

28. mereciera: merecia $(38: 5)$;

29. simio: jimio (38:22);

30. "un Sexto Aurelio, un Propercio": "un Sexto Aurelio Propercio" (38:163);

31. "hételo Guevara": "hételo a Guevara" (28:213);

32. "sin que haya quien, de limosna...": "sin que haya, ni aun de limosna..." (48:3);

33. "no está un / dedo de que profetice": "no está $a$ un / dedo..." (48:55);

34. "ParDios": "Por Dios" (49:105);

35. "me abate hasta el profundo": "me abate a lo profundo" $(57: 3)$;

36. "áspides que por flechas disparas": disparan (61:15);

37. "método a jazmines nevados": métodos (61:27);

38. "que cuanto los favores son más grandes, / tanto menos obligan a la deuda": "que cuando..." (65:37). (Este cuando de MP puede ser errata de imprenta.)

39. "aunque los que intenta son retornos": "aunque lo que intenta..." (65:43);

40. "tengo por acierto": "tengo yo, por cierto" (73:62);

41. "no sube puntos": "no sabe puntos" (87:43);

42. "y doylo, aunque non debiera": "aunque no debiera" $(88: 28)$;

43. Pigmaleón: Pigmalión (103:39);

${ }^{48}$ Yo tenía por buena la enmienda de MP, pero la nota de S\&R sobre este pasaje me hace cambiar de opinión. No es una oración aparte, sino continuación de la anterior: "Europa mejor lo diga..., / y cuantos el dulce lotos / de sus riquezas los hace / olvidar...", etc. Así enmendado, el texto muestra que sor Juana compartía el sentimiento de los criollos paisanos suyos. Ya Baltasar Dorantes de Carranza, en su Sumaria relación (1604), habla con rencor de quienes, habiendo llegado a la Nueva España como viles "grumetes o marineros", hacen fortuna y "consiguen la grandeza con que crecen en esta tierra, mormurando della y aniquilando ['ninguneando'] a los que lo merecen" (o sea a los criollos, de cuyos méritos no se hace caso). Sor Juana dice, pues: 'Mi patria es riquísima: dígalo Europa, díganlo esos que se enriquecen y luego se olvidan de la tierra que los enriqueció'. Cf. mi "Historia de la palabra gachupin", en Scripta philologica in honorem Juan M. Lope Blanch, México, 1992, t. 2, sobre todo pp. 282-287. 
44. “¿Posible es que no ha sentido / esta mano que le toca?": "que no has sentido / ...que te toca?" (103:45-46);

45: avenenados: envenenados (114:7);

46. "y haced libres alguna vez / de cuantas hacéis cautivos": "de tantas que hacéis cautivos" (125:20);

47. contraria: contrarias $(125: 22)^{49}$;

48. "Este concepto florido / devergel más oloroso": "delvergel más oloroso" (129:2);

49. "de quien tal regalo hizo": te hizo (130:8);

50. "con santo recelo": "con tanto recelo" (cf. infra, núm. 64) (137:21);

51. "poner bellezas en mi entendimiento, / que no mi entendimiento en las bellezas": pensamiento, / pensamiento (146:7-8) ${ }^{50}$;

52. "no se hable más en celo ni en sospecha": "en celo y en sospecha" (176:11);

53. "que diese como sol la vuelta al mundo": "como el sol" (187:14);

54. "a su recio natalicio ofrece / tutelar verde palma victoriosa": "a su regio natalicio ofrece / tutela verde, palma victoriosa" $(209: 3)^{51}$;

55. "pues y a no os puede usar la Musa mía": "ya no las puede usar la Musa mía" (214:58) 52 ;

56 "ese recelo": "este recelo" (214:193);

57. "uno en su boca, otro en la frente": "uno en la boca" $(214: 205)$;

58. "fui desgraciada": "fue desgraciada" (214:325);

59. "ni aun el costo": "el coste" (214:394);

60. Almone: Alcione (Sueño, v. 94);

49 "Dos cosas pretende aquí / contraria mi voluntad" (a saber, una libertad y una esclavitud). La enmienda de MP ("dos cosas contrarias") es muy comprensible; pero "voluntad contraria" (voluntad en dos partes dividida) es lectio difficilior que debe mantenerse.

50 Véase la tesis de Gabriela Eguía-Lis Ponce, La prisa de los traslados, UNAM, 2002, pp. 144-146.

51 Otro mea culpa: yo había aceptado la enmienda regio; pero "recio natalicio", como observan S\&R, alude a "las condiciones duras" en que nació Cristo. En cambio, S\&R aceptan la enmienda tutela; pero "tutelar, verde palma" hace muy buen sentido.

52 La errada enmienda de MP se debe a que puso entre paréntesis la cita de Garcilaso, que no es incidental, sino parte del discurso: "Oh dulces luces por mi mal halladas..., / pues ya no os puede usar la Musa mía”. (S\&R acentúan "por mí mal halladas"; creo que hay que leer, como en Garcilaso, "por mi mal".) 
61. tálamos: tálamo (Sueño, v. 721);

62. "Aguija, corre, corre, alija la carga": "Aguija, corre, corre, aguija, carga" (236:3) ${ }^{53}$;

63. "Elque sin tener caudal...": "Alque..." (239:31);

64. "con santo desinterés": "con tanto desinterés" (240:44) (cfi supra, núm. 50);

65. "un barbado": "un bárbaro" (241:43);

66. "que es consecuencia": "porque es..." (267:26) ${ }^{54}$;

67. "desprende sutil": "que prende sutil" (271:18);

68. "pero me han de ayudar todos": "pero que han..." (274:71);

69. "¿Qué es eso?": "¿Qué es esto?" (Loa al Rey-11, 233);

70. "déjense de aqueso": "de aquello" (ibid., 295);

71. "Y, mas qué voz...?”: "Y más, que vos..." (ibid., 480);

72. "los que las hacían / están ocupados": "las que... / están ocupadas" (ibid., 490-491);

73. "sola el alma": "sólo el alma" (Loa a la Reina, 4);

74. "que... / la gloria que representas / no llegue a pasada nunca": "no llegue a pasarse" (ibid., 178);

75. "con brújula": "por.brújula" (ibid., 245);

76. "y globo a sus pies pequeños": pequeño (ibid., 360);

77. [Pasado]: Presente; Presente: Pasado (ibid., 436, 440) ${ }^{55}$;

78. "vivan eternos": "vivid eternos" (ibid., 448);

79. pudieran: pudieron (Loa en las huertas, 16).

80. "Dejad, esperad...": "Dejad, parad..." (ibid., 210);

81. "para que, a querer la mesma...": "para creer que la mesma..." (Loa a fray Diego, 36).

\section{Lista IV. LECCIONES DESACERTADAS DE MP ACOGIDAS POR S\&R}

1. "que asegurarse en las dichas / solamente puede hacerlo / la villana confianza...": "que asegurarme..." (3:105);

2. "Al modo que ['del mismo modo que'] aquellos que...": "Al modo de aquellos que..." (3:265);

${ }^{53} \mathrm{~S} \& \mathrm{R}$ mantienen, con toda razón, alija la carga; pero creo que hacen mal en suprimir uno de los dos corre: la hechura de los versos de los estribillos suele ser más rítmica que silábica.

${ }^{54} \mathrm{El}$ porque (que está en ediciones tardías) hace más fluido el octosílabo; pero, según observan S\&R, basta hacer hiato (no sinalefa, como dicen por error en la nota) entre quey es.

55 Se trata de acotaciones. En la Inundación castálida falta la del v. 436, pero consta la del 440; MP las trastrueca. 
3. "que no ha de darle tu vista / a mis pesares aliento": "que no ha de darles..." (6:63) ${ }^{56}$;

4. "tengo yo": "tengo ya" (11:11);

5. bebe: beben (12:19);

6. "le intitulé Caracol": "lo intitulé..." (21:127) 57 ;

7. "acreedores... de flechas": "a flechas" (36:68);

8. "Copiar las flores a Mayo": "al Mayo" (39:179);

9. "están diciendo coméme": comedme $(43: 76)^{58}$;

10. "dísticos no de elegantes poemas": "dísticos no, elegantes poemas" (62:10);

11. "Édipo en enigmas": "en los enigmas" (62:25)

12. "acciones contextas": "acciones contestas" $(70: 56)^{59}$;

13. archero [palabra perfectamente normal]: arquero (75:6);

14. "es delito / el que se singularicen": singularice (92:120) ${ }^{60}$;

15. "con la razón lo que alcanzo, / y con fe lo que no entiendo": "con la fe lo que no entiendo" (106:30);

16. "Vuestra edad... / os la aumente Dios / como la merecéis vos": "como lo merecéis vos" (123:3);

17. "y así el que aquesta quintí-/ lia hizo y quedó tan ufá...", etc.: "y así el que aquesta quintilla / hizo...", etc. (144:6-10) ${ }^{61}$;

${ }^{56}$ MP y S\&R tienen, "gramaticalmente", razón para hacer plural el dativo: 'darles aliento a mis pesares'. Pero el le con valor de plural, frecuentísimo en nuestros días, está documentado ya en autores de los siglos de oro como Cervantes y Góngora: véase mi artículo de 2003, pp. 506-507, con la nota 18. Por lo demás, tanto MP como S\&R dejan a veces ese le con valor de plural: 'le sirven láminas a tus triunfos', 'le sujete a tus plantas la rueda' (62, vv. 53 y 70). Cf. infra, final de la nota 84 .

${ }^{57} \mathrm{~S} \& \mathrm{R}$ coinciden con MP en este lo acusativo; pero tanto ellos como él dejan intacto el $l e$ igualmente acusativo ("le desechan", "os $l e$ remito", "enmendarle") del mismo romance 21, w. 132, 133 y 137.

${ }^{58}$ Dicen S\&R que ponen "comedme en vez de cómeme". Más bien en vez de comeme, como dicen las adiciones antiguas (o sea comedme, con la bien conocida supresión de la $d$ de los imperativos; cf. en el Quijote, II, 59, las uñas de vaca que "están diciendo ¡Coméme, coméme!”).

${ }^{59}$ Sería raro que en dos casos (aquí y en el citado infra, núm. 85) se haya impreso contextar en vez del comunísimo contestar. No figura contextar en el diccionario, pero significa obviamente 'cotejar', 'confrontar un texto con otro', y de ahí 'comparar, relacionar una cosa con otra'.

${ }^{60} \mathrm{El}$ plural es muy defendible: la ley de Atenas (el ostracismo) no se aplica sólo a Aristides, sino a todos aquellos que se singularicen (cf. Respuesta a sor Filotea, lín. 533 ss.). Véase también infra, núm. 19. Por cierto, S\&R imprimen Arístides; pero etimológicamente es palabra llana (Aristídes); además, está en un romance de asonancia i-e.

${ }^{61}$ Fue evidentemente la condesa de Paredes quien le pidió a sor Juana que glosara una endiablada quintilla cuyo primer verso era "la acción 
18. "y advierta... / que no le escribo más este soneto / que porque todo poeta aquí se roza": "que le escribo, no más, este soneto / porque todo poeta aquí se roza" (158:13-14)62;

19. "Pues no soy la primera / que... / echan con mil primores / una mujer en infusión de flores": "la primera... / que... echa..." (214:25) ${ }^{63}$;

20. "el de reloj humano / vital volante": "el del reloj humano..." (Sueño, 205) ${ }^{64}$;

21. "centrifica oficina": "científica oficina" (ibid., 235)65;

22. "primogénito... / de Themis": "de Thetis" (ibid., 627)66;

23. "iVaya de jácara...!": "VVaya de jacaranda...!" (222:5);

24. "lo primero con que encuentro / es un seis, que no es más de uno": "y lo primero que encuentro / es un seis, que no es más que uno" (266: 10-11) (tres enmiendas gratuitas);

25. "que ir la reina hermosa": "que el ir la reina hermosa" $(272: 27)^{67}$.

religiosa de". Sor Juana se excusa: "Señora, aquel primer pie...", etc.; es imposible glosarlo en una copla terminada en de, preposición átona; y reta al autor de la quintilla a glosar una redondilla de pies quebrados (cosa aún más difícil): "...y así el que aquesta quintí.", etc. Creo que hay que respetarle su broma. - Por lo visto, la condesa insistió, y sor Juana acabó por hacer la glosa: véase infra, p. 131, con la nota 85 .

${ }^{62} \mathrm{MP}$ reconstruye los dos versos para evitar "la dura sinéresis de poeta" (y, de paso, le destruye a sor Juana el curioso hipérbaton del v. 13). La sinéresis de poeta (cuasi pueta) no es más violenta que la de maestro (cuasi maistro) en la Loa a fray Diego, w. 443 y 448. Estas sinéresis "abundan" en el siglo XVII, dice RAFael LAPESA, Historia de la lengua española, \$ 116.2.

${ }^{63} \mathrm{MP}$ enmienda el echan, pero deja intacto el sacan del v. 28. Creo que hay que entender 'No soy la primera de quienes echan... y sacan...' (infinitos poetas han echado a una mujer hermosa en infusión de rosas, jazmines, etc.). Cf. supra, núm. 14.

${ }^{64}$ La supresión del artículo es rasgo gongorino. El v. 135 del Sueño dice "y en otro guarda cálculo pequeño", y MP enmienda: "guarda el cálculo pequeño"; pero aquí S\&R han restaurado la lección original.

${ }^{65}$ Por lo visto, el adjetivo centrifica siempre causó extrañeza, y las ediciones posteriores a la primera lo cambiaron por científica. Pero el estómago no es una oficina científica, sinojustamente centrifica (palabra inventada quizá por sor Juana): es el centro distribuidor, la despensa central del organismo humano.

${ }^{66}$ Muy bien pudo sor Juana haber escrito Themis, la diosa restauradora de la vida después del Diluvio de Deucalión, como dice Ovidio (Metamorfosis, I, 321 y 379). Cf. H. J. Rose en el Oxford Classical Dictionary: "Themis, a goddess originally akin or even identical with Gaea".

${ }^{67}$ S\&R no sólo aceptan la enmienda de MP, sino que en el verso anterior ponen "con voces tïernas" (diéresis inaceptable), evidentemente para 
26. "Dizque los doctos de allá / la Ciudad de Dios os llaman / y de Ángeles": "Claridad de Dios os llaman" (282:74) 68; $^{6}$

27. "en quien quiso / que asi el arte se excediese...": "que $a$ si el arte se excediese" (319: 65) ${ }^{69}$;

28. "yo, que la más peregrina...": “ya que la más peregrina..." (319:77);

29. descollaste: descollante (321:14);

30. "y el de la Creación corona": "del de la Creación, corona" $(358: 16)^{70}$;

31. "¡Miren qué tiene que ver / años con sofisterías!": "qué tienen que ver..." (Loa al Rey-11, 285);

32. "en quien se admiran": "en quien se miran" (Loa a la Rei$n a, 437)$;

33. "A tu voz amorosa": "A tu voz armoniosa" (Loa en las huertas, 63);

34. “Tened, parad...!": “TTened, esperad...!" (ibid., 204);

35. “Dejad, esperad...!”: “Dejad, parad...!” (ibid., 210);

36. "vengan, vengan, vengan, / vengan todas las Prendas, / para hacer un compuesto / de todas ellas" (4 versos): "vengan, vengan, vengan todas las prendas, / para hacer un compuesto de todas ellas" (Loa a fray Diego, 5-6) ${ }^{71}$;

37. "haciendo, atenta, / el que las especies vivan" (elsustantivador): "haciendo, atenta / a que..." (ibid., 21);

38. "que ni almar crezca una gota": "que ni $e l$ mar..." (ibid., 81);

regularizar la métrica. Pero el verso "que ir la reina hermosa" puede leerse con hiato normal ("que I ir"), como en 276:26 ("que l es consecuencia grande"), verso respetado por MP y por S\&R.

68 Sor Juana pone esto en uno de los villancicos destinados a la catedral de Puebla de los Ángeles; dice que los poblanos llaman "Ciudad de Dios" y también "Ciudad de los Ángeles" a la Virgen María. La enmienda Claridad destruye lo que evidentemente quiso decir sor Juana.

${ }^{69}$ Para mí es claro que lo que debe leerse es así. La copla está en serie con las anteriores, en que un interlocutor le quita la palabra a otro, de manera que las coplas terminan en suspensivos. Aquí un interlocutor dice que la mayor de las Siete Maravillas es la estatua de Júpiter Olímpico, en la que Fidias quiso "que asi el arte se excediese / y se viese / lo que su estudio alcanzó...", pero no termina, porque el siguiente interlocutor lo interrumpe.

${ }^{70}$ El texto original (Inundación castálida) es perfectamente comprensible: la Encarnación es un eslabón de los sagrados Misterios: es medio del misterio de la Redención, y corona el de la Creación (corona, del verbo coronar).

${ }^{71} \mathrm{MP}$ convierte la seguidilla en dos versos largos para que éstos coincidan con los w. 118-119 (y de paso suprime uno de los tres vengan). Pero no hay razón para alterar la disposición original. Por otra parte, S\&R, extrañamente, añaden un que, aquí y en los vv. 117, 131 y 156: "ique vengan...!" 
39. "para que todo lo atiendan" (dicho de las cuatro prendas de fray Diego): "para que todo lo atiendas" (ibid., 131);

40. "y para que eslabones mejores sean / de que ha de fabricarse mejor cadena": MP y S\&R "se comen" el segundo de estos versos.

41. Y asi...: Así... (ibid., 165);

42. "como en anuales obsequios": "en anüales obsequios" (ibid., 206);

43. "se halla [la Ciencia] en su [del Agrado] modo de obrar": "lo halla..." (ibid., 297);

44. "Segunda $A$ traigo yo, en que / el Agrado se demuestra": "Segunda $A$ traigo yo, / en que el Agrado se muestra" ( $i b i d ., 316-317$ );

45. "Híncanse de rodillas los hombres y mujeres, y están postrados mientras danza el Occidente", acotación omitida por MP y por S\&R (loa de El divino Narciso, a continuación del v. 14);

46. "el [beneficio] de conservar la vida / como el mayor estimamos": "como el mayor lo estimamos" (ibid., 51);

47. "que adoro al gran dios...": "que venero..." (ibid., 246);

48. "que es, en mis amantes voces, / una cosa la que entiende / y otra cosa la que oye": "que, en estas amantes voces, / una cosa es la que entiende..." (El divino Narciso, 153-154);

49. "no merezca": "se merezca" (ibid., 416) 72 ;

50. "llegue a lograr, y asi es bien / que...": “...llegue a lograr. Asi es bien..." (ibid., 451);

51. "natante tabla": "nadante tabla" (ibid., 481);

52. apetecible. apetecido (ibid., 871);

53. me di: dime (ibid., 1074 [984]) ${ }^{73}$;

54. "desde que a ser empezó / su corriente": "desde que ayer empezó..." (ibid., 1155 [1065]) 74 ;

55. "de si se enamore" (como el Narciso ovidiano): "de $t i$ se enamore" (ibid., 1167 [1077]);

56. "[El giro del sol] con todo el curso luciente / que da...": "en todo el curso..." (ibid., 1331 [1241]);

72 Bien puede defenderse la lección de la ed. de 1691: 'temerosa de que la naturaleza humana no merezca los laureles que yo perdî' (a imitación de la construcción latina timeo ne). En todo caso, la corrección de 1692 (" más venturosa, merezca") es preferible a la de MP.

${ }^{73}$ En el teatro no son raras las inversiones del tipo me di por 'dime'; y tanto MP como S\&R mantienen el me da 'dame' del v. 1099 [1009]. (Para los números entre corchetes véase supra, nota 20.)

${ }^{74}$ La lección "desde que a ser empezó" (o sea ab initio) es enmienda que 1692 hace de la absurda lección de 1691, "desde que ayer" (!). 
57. "los ojos..., / ...en su resplandor, / muestran, con luces de sol, / benignidad de paloma": "entre su arrebol / ...con luces del sol" (ibid., 1363 [1273]) ${ }^{75}$;

58. "Las piedras, enternecidas, / rompiendo su seno duro": "su ceño duro" (ibid., 1719 [1629]);

59. "al discurso": "del discurso" (ibid., 1805 [1715]) 76;

60. "Busco a mi dueño amado / y ignoro dónde...": "...amado; / ignoro..." (ibid., 1941 [1851]);

61. "tuvo el ser en su cuidado / y se perdiera en su olvido": "y se perdiera a su olvido" (ibid., 2102 [2012]) ${ }^{77}$;

62. "suceder en el trono": sucederle (El mártir, 279);

63. engazan: engarzan (ibid., 332) (cf. Sueño, 659: "bisagra engazadora");

64. "en dos iguales balanzas, / mi padre y mi religión, / no sé cuál más peso traiga": "no sé a cuál..." (ibid., 350)78;

65. las dogmas: los dogmas (ibid., 517) ${ }^{79}$;

66. "ya te esperan / sus abrazos paternales": "ya te espera / con sus brazos paternales" (ibid., 589-590);

67. "ocasión / a que una guerra se trate": "se trabe" (ibid., 596);

68. "puntos tan graves / como el de la religión": "punto tan grave..." (ibid., 616);

69. "nos precisa el tiempo": "nos precisa el riesgo" (ibid., 1446);

70. "siendo ya fijo imperio, / ...que puede / conservarse sin recelos": "...bien puede" (ibid., 1613);

71. "de cuanto el Betis baña, / parte mojor": "en cuanto el Betis..." (ibid., 1726);

72. "y así, aunque me ves postrada, / no tanto que...": "no es tanto que..." (loa para El cetro de José, 257);

73. sacrificarlas (las ofrendas): sacrificarla (ibid., 298);

74. intento: quiero (El cetro de José, 22);

${ }^{75} \mathrm{MP}$ pone arrebol para que rime con sol; pero se trata de una "equivalencia acústica" idéntica a la de los w. 180-181 del mismo auto, donde MP "permite" que rimen resplandor y farol. (Por lo demás, el arrebol les estará bien a las mejillas, ipero no a los ojos!)

${ }^{76} \mathrm{La}$ ed. de 1691 dice " $e l$ discurso", pero la de 1692 corrige: "al discurso", que es la lección buena: no habrá quien le borre al discurso humano sus hábitos pecaminosos.

77 De nuevo, la lección de 1692 es la buena; la de 1691 omitía la preposición. Cf. la simetría "en su cuidado" / "en su olvido".

${ }^{78}$ Aquí, el texto bueno es el de la ed. de 1715; las anteriores dicen " $a$ cuál".

${ }^{79}$ Ciertos sustantivos masculinos terminados en - $a$ solían feminizarse: centinela, enigma, fantasma (cf. Sueño, 869)...; bien puede entrar dogma en esta categoría. 
75. "y a la futura": "y la futura" (ibid., 95) ${ }^{80}$;

76. "[Tu generación será innumerable], y en ello todas las gentes / alcanzarán bendición": "y en ella" (ibid., 236);

77. "Yo soy el Dios verdadero / de Adán tu padre, y de Isaac": "de Abraham tu padre..." (ibid., 245) ${ }^{81}$;

78. "para cualquiera que subir intente, / ... [y para] dar tránsito a la tierra para el cielo": "da tránsito" (ibid., 281);

79. "Calla, no prosigas": "Calla, no ya prosigas" (ibid., 320) ${ }^{82}$;

80. "viendo que ya voces daba": "viendo que yo..." (ibid., 437);

81. "Y no hallándose / quien entienda": "Y no ha halládose" (ibid., 650) ${ }^{83}$;

82. "Ya que del solio excelso...": Ved que... (ibid., 867);

83. "pues ignora, o sabe, que...": "pues o ignora..." (ibid., 1057);

84. "serán de su progenie [de= 'por'] / todos los hombres benditos": "en su progenie" (ibid., 1542);

85. "contextar con mi persona / intentaban mis aplausos": "contestarcon mi persona" (cf. el núm. 12 de esta lista) (Los empeños de una casa, 1, 387);

86. "Aliento y vida me falta": me faltan (ibid., 876);

87. "mi vida y mi honor peligra": peligran (ibid., 927).

${ }^{80} \mathrm{El}$ texto original dice: "las distancias midamos / de la pasada edad, y $a$ la futura / primicias le dará a la Conjetura". Obviamente, una de las preposiciones $a$ está sobrando (y estorbando). MP quita la primera; según yo, la que hay que quitar es la segunda. Lucero (o sea el Demonio) observa lo que hace y sufre José, y barrunta que debajo del sayal hay ál: ¿no será José "tipo" o "figura" de otra cosa? Solicita entonces la ayuda de la Ciencia para medir las distancias de la pasada edad, con lo cual la Conjetura podrá dar las primicias " a la futura edad". (José es prefiguración de Cristo; la pasada edad es el pecado de Adán y Eva; la futura es la Redención; pero esto lo saben los espectadores del auto sacramental; Lucero no lo sabe.) Poco después, vv. 176177 , la Conjetura en persona declara que, según las señas, Dios quiere redimir al hombre: "Luego bien conjeturo / que intenta remediarle en lo futuro" (tales son las primicias que se le dan "a la futura edad").

${ }^{81}$ Esto se lo dice Dios a Jacob. La enmienda de MP me parece equivocada, y creo que el texto original está bien: 'Yo soy el Dios de Adán, padre tuyo (y de todo el género humano); yo soy el Dios de Isaac, el padre que te engendró'. (Abraham no es padre, sino abuelo de Jacob.)

${ }^{82}$ MP endereza el verso cojo mediante una sintaxis violentísima; más simple es enderezarlo así: "Cállate, no prosigas".

83 Otra construcción violenta de MP, esta vez para darle un eje verbal a la oración. Creo que hay que dejar el "no hallándose", y explicar que, a causa de las varias oraciones incidentales que siguen, se le escapó a sor Juana el hilo del discurso (anacoluto se llama esta figura). En el Sueño hay un accidente parecido, a partir del v. 152. 
Añado algunas observaciones sobre el texto. En primer lugar, S\&R, que mencionan mi edición de los Enigmas en la nota respectiva (y también en la p. liii, nota 18), no parecen haber hallado digno de mención lo que allí digo, pp. 150-154 (y repito en mi artículo de 2003, pp. 522-523) sobre el "manuscrito Moñino", para mí tan interesante. Se salvó de milagro, cuando tantas otras copias (como las que menciona sor Juana en el romance-dedicatoria: supra, p. 110) se desecharon al aparecer los tomos impresos. Es el único manuscrito antiguo que tenemos de versos de sor Juana: copia de alguna otra copia, en vista del número de disparates que contiene; pero conserva lecciones que obviamente estaban en el original, y que los impresores alteraron. Si yo hiciera una edición crítica, aprovecharía sin vacilación ese raro manuscrito. Allí se lee "quien está temiendo el riesgo" (3:128) y "porque sus números viendo" (48:21) en vez de las lecciones erróneas de todas las ediciones, sintiendo y murmurios ${ }^{84}$; en el romance 38 , a continuación del v. 196, hay una cuarteta que los impresores se saltaron (es nada menos que el remate de la enumeración de ingenios femeniles que comienza en el v. 173); y, sobre todo, hay allí una composición entera de sor Juana que nunca se imprimió: glosa, en cinco coplas reales, de una quintilla en loor del rey ${ }^{85}$.

${ }^{84}$ Los impresores, en estos dos casos, fueron víctimas del "síndrome de palabra vecina": repiten las voces sintiendo y murmurios que hay en el verso que antecede. Este síndrome explica erratas como "si ellos dientes son" (214:70: falsa concordancia de ellos y dientes, masculino plural; debe ser ellas: las perlas), o "Si es causa Amor productivo" (3:1: falsa concordancia de Amor. y productivo; debe ser productiva: la causa). Cf. también "confites... les das" (72:4, en vez de le al gusto); "no tuvo para la alteza" (261:13, en vez de "para él alteza"); Sueño, v. 964 "que ha dejado / el sol desamparado" (en vez de desamparada: la mitad del globo). Etc. - También hay el "síndrome de letra vecina". En la Inundación castálida se lee: "y una razón de belleza, / belleza de la razón" (Loa a la Reina, 352-353), y MP corrige sagazmente: "y 'úna, a razón de belleza, / belleza de la razón": acentúa úna para señalar cómo la adición de la preposición a convierte lo que parecía artículo ("una razón") en subjuntivo del verbo unir. Me parece un ejemplo claro de ese síndrome: falta la preposición porque el oficial de la imprenta "cree" que ya ha puesto la $a$ (al final de "un $a$ "). Otros casos así pueden verse en mi artículo de 2003, pp. 508-509; y cf. supra, Lista I, núm. 15. Seguramente se deben también a este síndrome los dos casos de le en vez de les que menciono supra, final de la nota 56: el le va seguido de una s (sirven, sujete).

${ }^{85} \mathrm{He}$ aquí la quintilla, propuesta en una "academia" madrileña (de la cual doy noticia en $N R F H, 26,1977$, pp. 399-400): "La acción religiosa de / Rodulfo y de Carlos dio / cetro al Austria, pues su fe / cedió el trono, pero 
En 3:277-280 pasa sor Juana del tú ("el intento tuyo") al vos ("acudistes al partido..., hallastes, ayudastes"). Es fenómeno bastante frecuente (sobre todo en el teatro). MP deja tal cual la cuarteta; S\&R, en cambio, la ponen en tú: "acudiste al partido..." (octosílabo muy cojo), etc.

En 16:43 creo que no hay que leer tormentos, sino tormentas, en oposición a las bonanzas del v. 44. Cf. Los empeños de una casa, 1, 219220: "y si está así en la bonanza, / ¿cómo estará en la tormenta?"

Romance 19, w. 157-160: "y si un filósofo, sólo / por ver al Señor de Delos, / del trabajo de la vida / se daba por satisfecho...". Nota de MP: "Cuál fuera ese filósofo, lo ignoramos". Nota de S\&R: "Se habla de Apolo como el dios de las artes y las ciencias, de ahí que el «filósofo» (¿Aristóteles?) se diera «por satisfecho... del trabajo de la vida» al verlo". En adelante ya no habrá que quebrarse la cabeza. No hace mucho, en mi seminario de poesía de los siglos de oro (UNAM), al analizar este romance, dije yo lo mismo que MP, y entonces uno de los estudiantes, llamado Eduardo García Anaya, exclamó Eureka! y resolvió el enigma: ese filósofo es Diógenes, que se daba por perfectamente feliz con sólo recibir de lleno la luz del Señor de Delos (Apolo, el Sol), sin el estorbo de la sombra que le hacía Alejandro.

En el romance 20, dirigido a la condesa de Paredes en un cumpleaños, le dice sor Juana: 'Deseo para ti más años de vida que...', pero no se vale de las imágenes consagradas ("más que arenas hay en las playas", "más que estrellas tiene el cielo", etc.), sino que acude a una serie muy recherchée de imágenes mitológicas: más que las gotas de sangre caídas de la cabeza de Medusa sobre Libia; más que los gritos en que prorrumpió Polifemo al ver a Galatea en brazos de Acis, etc. La primera de las nueve imágenes dice: más que los ardientes dolores padecidos "en el

no / glosarán cómo o por qué". El epígrafe explica que "[se hizo] en Madrid esta quintilla a la acción católica de nuestro monarca Carlos segundo el año de 168. [léase 1685] ..., la cual quintilla pasó a México y la glosa la autora”. Los cinco pies, y no sólo el primero, son inglosables. He aquí cómo sale sor Juana del paso en la glosa del primer pie: “¿Cúya pudo ser la acción / llena de tanta piedad [...]? / No se diga de quién fue [...], / bastará con apuntar / la acción religiosa de". (Pudiendo haber cambiado el $d e$ en $d e ́$, y decir, por ejemplo, '...tema para mil loores / la acción religiosa dé', prefirió decir: 'Si de acción religiosa se trata, no puede ser sino de nuestro pío monarca; ni falta hace poner su nombre a continuación del $d e$ '. - Es evidente que sor Juana hizo esto a contrapelo, y por eso decidió que no se imprimiera.) 
leño encendido" por el amante de Egea, a causa de "la venganza del tío". S\&R imprimen Egina en vez de Egea, y "lecho encendido" en vez de "leño encendido", y defienden estos cambios aduciendo un oscurísimo mito de Egina y Júpiter, que en verdad no explica nada. Según yo, "leño encendido" está perfectamente bien: es la famosa hoguera en que Hércules (Hercules Oetaeus) puso fin a su existencia; es la culminación de una vida de sufrimientos que le impuso su tío (Euristeo) por instrucciones de la celosa y vengativa Juno. La multitud de dolores de Hércules está en serie con la multitud de gotas de sangre de Medusa, la de gritos de Polifemo, etc. En cuanto a Egea, no puede ser sino errata por Auge (verosímilmente Augea), de quien Hércules fue amante, como dice Ovidio, Heroida IX, v. $39^{86}$.

Al comienzo del romance 24, escrito en ocasión del bautizo del hijo de la condesa de Paredes, le dice sor Juana (texto de la Inundación castálida): "Crédito es de tu piedad / que... tú le quieres [bautizar]". Pero la sintaxis pide el subjuntivo: 'Es crédito de tu piedad que lo quieras bautizar'; $c f$. la continuación: 'y que no estimes la ley de naturaleza habiendo sobrevenido para el bebé la ley de gracia' (y aquí sí consta el subjuntivo en la Inundación castálida). S\&R dejan intacta la inconsecuencia sintáctica (quieres, estimes); MP pone los dos verbos en indicativo (quieres, estimas); yo siento que deben estar en subjuntivo (quieras, estimes). Cf. supra, Lista I, núm. 56, donde MP y S\&R sí restauran la concordancia modal.

En 25:79 le dice sor Juana al hijo de la condesa, cuando cumplió un año de vida: "Ya habéis visto doce signos, y... vencido doce trabajos". Tal es la lección que propongo, en vez de “venciendo doce trabajos", que deja en el aire la conjunción y.

En el mismo romance menciona sor Juana a la madre del niño, llamándola "la Leda de tal Apolo, / de tal Cupido la Venus"; Apolo no es hijo de Leda, personaje tan conocido, sino de Latona (que no cabe en el verso). Yo creo que sor Juana empleó la forma griega de Latona, que es Leto. (En la literatura de los siglos de oro puede hallarse Afrodita en vez de Venus, o Poseidón en vez de Neptuno.) La errata Leto $>$ Leda es muy comprensible.

26:39: alusión al delfín que le salvó la vida a Anfión, obvia confusión con Arión. Quizá se trate de un lapsus de sor Juana, y

${ }^{86}$ El cambio Auge > Augea sería como Casiope > Casiopea. También puede haber habido contaminación con Augeus (Séneca, Hercules furens, v. 247). En la misma Heroida IX, v. 147, se menciona la hoguera. 
por eso MP lo dejó tal cual. S\&R imprimen Arión, y explican debidamente la razón de la enmienda. En una edición estrictamente crítica, este Arión iría entre corchetes ${ }^{87}$.

La enmienda que hacen S\&R en 31:7, "ambas habremos cumplido" en vez de "ambas habemos" me parece excelente en cuanto al sentido, y también en cuanto a la sintaxis.

En 46:22, según pienso, debe leerse "pudiera $a$ hacer" en vez de "pudiera hacer"; la preposición a es necesaria: "Vos, de quien Tácito pudiera aprender a hacer sus doctos escritos'.

En 46:135 dice la Inundación castálida que la esmeralda "se roba la luz al cielo", verso enmendado en 1690 (y en MP, y en S\&R): "la luz del cielo". Yo creo que la enmienda debe ser otra: no "se roba", sino "le roba". El paralelismo es perfecto: "le roba la luz al cielo y le usurpa los visos al campo'.

Al comienzo del romance endecasílabo "Celebrando los años de un caballero", dice el Segundo volumen: "círculos que ha cumplido..., cláusulas que han cerrado". MP y S\&R uniforman "han cumplido", "han cerrado". Yo creo que hay que uniformar de otra manera: es el dia el sujeto de los verbos. Si el caballero cumple 35 años, el dia de su cumpleaños 'ha completado 35 círculos de luces, ha puesto punto y aparte en 35 cláusulas de estrellas'.

Dice sor Juana que no es posible corresponder a un favor cuando éste nos viene de una deidad; y en el Segundo volumen se lee: "de la deidad se admire el beneficio / y no se corresponde" (65:45); pero el sentido ('lo único que nos queda es admirar el favor') pide "de la deidad se admira el beneficio / y no se corresponde" (hacerlo, sería hasta ofensivo para la deidad, pues nos estamos poniendo de igual a igual con ella). Según yo, la enmienda de MP y de S\&R, "se admite el beneficio", está equivocada.

El chacho de 160:3 es, según MP (seguido por S\&R), abreviatura de muchacho; según yo, una errata. La traviesa autora pondera en los cuartetos del soneto la habilidad maravillosa que tiene Teresilla, "tan muchacha", de ponerle los cuernos al pobre de Camacho, su marido; y en los tercetos pondera la frecuencia con que el vientre de Teresilla "desembucha" criaturas engen-

${ }^{87}$ Claro que no es deseable una edición tan "estricta", pues los textos quedarían feamente plagados de corchetes. Me llama la atención que tanto MP como S\&R empleen los corchetes en un solo caso: "con lo mismo que [la alienta]" (53:40). 
dradas por distintos amantes (no por Camacho). Ese chacho, que está en el primer cuarteto, tiene que ser cacho 'cuerno'88.

Responder a un soneto "por los mismos consonantes" (consonantes forzados) podía entenderse de dos maneras: usando sólo la misma consonancia ( $-a d a,-e z a$, etc.), o repitiendo entera la palabra-rima (para decir lo contrario), cosa más difícil. Sor Juana toma la vía difícil en los sonetos 181 y 182, con la particularidad de que en el 181 está replicando a lo que ella misma dice en el 180. Pero en los dos casos metieron la pata los impresores, haciendo a sor Juana infractora de la dura lex. La palabrarima agraviarte (181:7) debe estar también en 180:7, donde la Inundación castálida pone olvidarte; y la palabra-rima pudiera (182:2) debe cambiarse por quisiera, como se lee en el soneto anónimo al que sor Juana contesta. Curiosamente, MP corrige lo primero y no lo segundo; S\&R mantienen los dos palmarios errores $^{89}$.

Por otra parte, creo yo que en 182:3 hay que corregir lo que seguramente es errata de todas las ediciones: no "alguno que tus prendas conociera", sino alguna, la misma del v. 9: "aquella que te hubiere conocido".

En vez de "es tan mísero estado en el que peno, / que como dicha envidio el mal ajeno", creo que hay que leer "es tan mísero estado el en que peno..." (213:17).

El chispeante retrato de Lisarda ("El pintar de Lisarda la helleza...”) tiene 396 versos en MP y sólo 394 en S\&R, los cuales,

88 La palabra chacho es muy rara. No figura en la abundante silva de consonantes del Arte poética de Rengifo (donde sí figura cacho). En el romance de Góngora "Manzanares, Manzanares...", v. 92 ("el juego del hombre, padre / de chachos o de codillos"), chacho es "lance de un juego de naipes' (cf. Romances de Góngora, ed. Antonio Carreira, t. 2, p. 451). En cuanto a cacho 'cuerno', cf. CovarRuBias: cachas, 'los cabos de los cuchillos, por hazerse de pedaços de cuernos'; y LOPE DE VEGA, Servir a señor discreto, ed. Frida Weber de Kurlat, p. 187: cosa de cachas 'cosa de cuerno (o de cuernos)'. Ángel Pariente, "La etimología de cachopo", RFE, 61 (1981), p. 219, registra cacho 'cuerno', "muy extendido en la América hispánica, pero del que hay antecedentes en Andalucía”. Ésta debe de ser la explicación de cachidiablo, y no la que -con "quizá"-ofrece Corommas, s.v.

${ }^{89}$ Además, en el 180 viene a quedar repetida la palabra olvidarte (wv. 2 y 7) y en el 182 la palabra pudiera (también vv. 2 y 7 ), chambonada inimaginable aun en el más pedestre sonetero. - En el soneto-respuesta al de sor Juana, "Érase un preste cara de testuz", fray Luis Tineo procuró mantener las palabras-rimas, pero cometió tres pequeñas infracciones en alcuzcuz, merendón y abadejón (usó palabras muy parecidas). 
por desdicha, se saltaron los vv. 46 y 54 . Creo, por cierto, que el v. 218 no es "mas, ¿qué piensan que digo de Cupido...?", como imprimen MP y S\&R, sino “'mas que piensan que...?”, etc. (que conijunción). Después de declarar que, por supuesto, las cejas de Lisarda son arcos, sor Juana les dice a los lectores (o a los oyentes): 'Ustedes estarán esperando una comparación con el arco de Cupido o con el arcoíris, ¿no es verdad? Pues no, señoras y señores, ahí les va una comparación nada trillada: ¡son como los arcos de un acueducto!'

La muy desarrollada imagen del Epinicio al conde de Galve, w. 16-24 - "conceptos mal formados", "informes embriones", partos "no sazonados", fetos concebidos de "lumbres claras", engendrados por el "divino ardimiento" del conde de Galve--, es evidente alusión al mito de Sémele y Júpiter (Ovidio, Metamorfosis, 3, 253-315). El virrey es un Júpiter (pues la derrota de los franceses en Guarico vale como hazaña suya); la mente de sor Juana -su estro poético - es una Sémele, abrasada por tamaños ardores; y el informe embrión es el Epinicio, abortado como un Dioniso, el hijo "mal formado" de Júpiter y Sémele. Esta elucidación no es mía, sino del mismo Eduardo García Anaya que detectó en el romance 19 la alusión a Diógenes.

En el v. 32 del Epinicio hay un "pavoroso ceño" que es una pavorosa errata: la "preñada nube" no se desgarra el ceño, sino el seno (y brota de él un rayo tremendo) ${ }^{90}$. Además, tiene que haber consonancia con el v. 30: trueno. Tanto MP como S\&R imprimen ceño. (Probablemente sor Juana escribió ceno.)

Para el Primero sueño dicen S\&R que han "tenido en cuenta" mis "Notas..." de NRFH, 43 (1995), 379-407, y me alegro de que en varios casos hayan aceptado mis propuestas; pero me sorprende que no les haya hecho mella lo que digo (p. 402) sobre las absurdas hijas de la rosa, errata tan obvia, según yo, por hojas. Seguramente aquí sor Juana recuerda a Góngora (soneto "Los blancos lilios que de ciento en ciento..."): "frescas rosas" que el viento acaricia, "como quien de una y otra hoja espera / purpúreas alas, si lascivo aliento".

${ }^{90}$ Este pasaje -dicho sea de paso- es una de las muchas muestras de la admiración que tiene sor Juana por Agustín de Salazar y Torres, el cual dice en la loa de su comedia Elegir al enemigo, vv. 401-404: "En el Fuego el rayo airado, / que de la nube preñada / víbora ardiente, al nacer / rompe las duras entrañas". - Otro caso de seno convertido en ceño puede verse supra, Lista IV, núm. 58. 
En 241:19 (coplas "de negro") dice la Inundación castálida: "poro que yo la oblaje vivo", 9 silabas; MP remedia la hipermetría imprimiendo "porque yo..."; S\&R la enmiendan mejor, y salvan el pintoresco poro ("pero"): "poro yo la oblaje vivo" (sin el que).

En el villancico "Para cantar con decoro" (núm. 261), algún raro accidente de la edición de $S \& R$ ha hecho que las quintillas tengan, tipográficamente, hechura de cuartetas. Y a este propósito diré algo que me parece lamentable: en muchos pasajes de los autos sacramentables y de Los empeños de una casa, S\&R no marcan tipográficamente, con sangría, el comienzo de liras, décimas, redondillas, etc.

Para las coplas de "Vizcaíno" con que termina el villancico 274 (Asunción de 1685), S\&R han acudido a un experto, Juan Bautista Avalle-Arce, y por eso el texto que imprimen difiere algo del de la Inundación castálida y del de MP; por ejemplo, "nerevici Gucico Galdunai" (Inundación), "nere Bizi, guzico Galdunái" (MP), "nere bici guzico galdunai" (S\&R). Según Avalle-Arce, no hay en vascuence "ninguna palabra aguda", lo cual no vale aquí, pues se trata precisamente de un romance de asonancia aguda (-á en los versos pares y en los dos del estribillo): los propios S\&R imprimen lastaná y no lastana. Evidentemente sor Juana estaba poco familiarizada con el vascuence (como también con el portugués: cf: el "Timoneiro que governas..." del villancico 249). En una edición crítica, lo más sensato sería dejar intactos los disparates, y comentar en nota todo lo comentable ${ }^{91}$.

${ }^{91}$ Por lo visto, también es aquí un tanto problemática la traducción de las palabras y frases vizcaínas. José Manterola, Cancionero basco, t. 3, San Sebastián, 1880, pp. 261-263, que fue el primero que se ocupó de estos versos, corrige algo el texto (v. gr. galdunaiz en vez de galdunai) y traduce lo vascuence; MP, que no leyó a Manterola (cosa muy explicable), les pidió ayuda a dos vascos residentes en México; después, R. LAFon, "Phrases et expressions basques dans un villancico de Sor Juana Inés de la Cruz", BHi, 56 (1964), pp. 178-180, encontró más acertado a Manterola que a los informantes de MP; sin haber leido a Lafon, Cegilia Guilarte, Sor Juana Inés de la Cruz (Claro en la selva), México, 1958 (2ª ed., Bilbao, 1970), se apoyó en Manterola, y Ángel Luis Lopez Gonzílez, "Sobre el origen vasco de sor Juana Inés de la Cruz", Cartelera Heráldica, Madrid, nov.-dic. 1974, copió (sin confesarlo) a Guilarte. He aquí las diversas traducciones del estribillo: "iAy, que se va! Me he perdido, / para toda mi vida me he perdido" (Manterola); "¡Ay, que se va lo que no quiero perder, / mi vida, todo lo que no quiero perder!" (informante 1 de MP); “ ‘Ay, que se va, estoy perdido, / mi vida! ¡Estoy del todo, estoy perdido!" (informante 2); ":Ay, que se va! Te quieres perder, / mi vida, te quieres perder del todo" (Avalle-Arce). Los versos de la última cuarteta, "Guatzen, galanta, contigo, / guatzen, nere lastaná", tienen en Manterola 
En la Loa al Rey-ll hay dos pasajes problemáticos. Los comentarios de la Música a lo que dice cada personaje alegórico están siempre en seguidillas de 7-5-7-5. Ahora bien, los wv. 205-206 dicen así en la Inundación castálida: "Que si compuesto / seralma y cuerpo..."; la fe de erratas, que ordena corregir: "es alma y cuerpo", no dice nada sobre "Que si compuesto", pentasílabo que debiera ser heptasilabo. MP lo remedia así: "Que si elcompuesto humano / es alma y cuerpo..."; el remedio de S\&R es más simple: "Que si compuesto $e l$ ser / es de alma y cuerpo..."; pero $e l$ ser es resulta muy violento. El v. 257 de la misma Loa, comienzo de seguidilla, es hexasílabo en la Inundación castálida: "Que si en Carlos vemos"; MP corrige: "Que si vemos que en Carlos"; S\&R prefieren "Que si ya en Carlos vemos". Yo creo que aquí no hay necesidad de retoques: las seguidillas de 6-5-7-5 no son raras.

El divino Narciso necesita una edición crítica, hecha a base de tres textos: el de la edición suelta de México, 1690, el de la $3^{\underline{a}}$ ed. del tomo 1 (1691) y el del Segundo volumen (1692). S\&R reproducen simplemente el texto editado por MP. Lo que hacen es enmendar la numeración de los versos a partir del 900 (véase supra, nota 20 ).

En la loa de El mártir del Sacramento dice Cristóbal Colón (vv. 261 ss.) que ya no vale el Non plus ultra, pues su timón rompió "el sello / que Abila y Calpe cerrado / tuvieron tan largos tiempos" (Abila y Calpe, los promontorios que flanquean el estrecho de Gibraltar). MP acentúa indebidamente Ábila, y S\&R no sólo hacen lo mismo, sino que alteran el verso: "del Ábila y Calpe cerrado". En la misma loa, el v. 289, "¿o a qué fin nos lo acuerdas?", heptasílabo en un romance, fue corregido por MP: "¿y con qué fin nos lo acuerdas?”, y S\&R lo copian. A mí la locución ¿con qué fin? ('¿para qué?') me suena moderna. Encuentro preferible otra solución (y más simple): “¿o a qué fin nos lo recuerdas?"

En la loa de Los empeños de una casa, v. 9, hay una enmienda muy sagaz de S\&R: no "al gusto de la Fineza", sino "de la Fortuna". Además, en el cuerpo de la comedia (I, 216; II, 778) rechazan,

esta traducción: "Vamos, hermosa, contigo, / vamos, amada mía" (seis palabras); y ésta en MP: " ¿Nosotros en pos tuya, contigo, Hermosa! / „Nosotros en pos tuya, oh Amada mía!" (trece palabras); Avalle-Arce se muestra vacilante: "Si el villancico sigue dirigido a la Virgen, entonces: "nosotros ( $g u$ ) detrás (atzén) [palabra aguda, por cierto], hermosa (galanta)'. Si de buenas a primeras estuviera dirigido al Niño [i en unos versos a la Asunción!], entonces güatzen ('a la cama'), galanta ('niño guapo'). Observo que S\&R imprimen justamente güatzen. 
con razón, las lecciones de Salceda y restauran las originales. En la misma comedia (II, 57-72) hay unas redondillas no anotadas por S\&R, y que Salceda, acertadamente, relaciona con las famosas de los "hombres necios". En efecto, sor Juana condena (por boca de Don Carlos) las "malicias erradas" con que los galanes suelen juzgar a las damas. Pero el texto "nunca ellas obran más bien / que cuando las tratan mal" necesita corrección: sor Juana no pudo decir semejante barbaridad. Obviamente hay que leer "que cuando los tratan mal": las mujeres hacen requetebién cuando tratan mal a esos groseros malpensados (es una manera de educarlos). Todas las ediciones traen la lección errónea. Salceda dice que "podría pensarse en una errata" (las en vez de los), pero desecha esa idea porque no consta el antecedente del pronombre los (a lo cual se puede contestar que tampoco consta el antecedente del pronombre ellas;uno y otro están sobreentendidos).

Para la Carta al padre Núñez, S\&R no han acudido al texto del manuscrito, reproducido fotográficamente por don Aureliano Tapia (Monterrey, 1993), sino que se han atenido a la lectura que de él hizo el mismo Tapia. Pero en este manuscrito hay erratas que yo me esforcé en corregir en mi edición de NRFH, 35 (1987), pp. 618-626. He aquí tres de mis correcciones: 1) línea 95: "los aplausos que tanto le duelen" (en vez de "se duelen": a Núñez le duele el ver aplaudida a una monja que debiera estar quietecita en su celda); 2) lín. 156: "la república... no cuida de lo que no le ha de servir" (en vez de "lo que no les ha de servir" (en vez de "lo que no les ha de servir": la "república", en efecto, no necesita mujeres "para el gobierno de los magistrados"); 3) lín. 253: "V. R. ha dado en ser mi padre, cosa en que me tengo por muy dichosa" (en vez de "me tengo ser", que no tiene sentido). Ni Tapia ni S\&R aceptan mis correcciones. Y hay algo peor. En el manuscrito -y en mi edición, lín. 196- se lee: "Yo tengo este genio. Si es malo, yo me hice. Nací con él y con él he de morir" (enérgica y admirable declaración, análoga a la del romance "Daros las pascuas, señora...", vv. 5-24: 'Así soy, y así seré siempre'). El copista escribió naci conel (sin separación entre con y el), y Tapia leyó esto por partida doble, incorrectamente primera, como racional, y correctamente después, como naci con él; yuxtapuso entonces las dos lecturas, a; adió un no, y el resultado fue "yo no me hice racional, nací con él”, disparate fielmente copiado por S\&R.

Comentaré finalmente algunas de las notas de S\&R, siguiendo, como siempre, el orden que tienen los textos en MP. 
Romance 2, epígrafe: "Acusa la hidropesía de mucha ciencia...". Está bien que la hidropesía sea 'acumulación mórbida de serosidades...', etc.; pero en tiempos de sor Juana era simplemente 'sed excesiva'. (Cf. v.gr. Góngora, Soledad I, v. 109: la Ambición, "hidrópica de viento".)

Romance 36. Según S\&R, "no es fácil de explicar el epígrafe" ("Da cuenta una de las señoras...", etc.). Yo creo que sí es fácil de explicar. Para un sarao de año nuevo fue obligación de las damas de la corte escribir (y, seguramente, leer ante la concurrencia) unos versos dedicados al galán que le hubiera tocado por sorteo. La monja sor Juana "se sustituye" en este juguete poético a la damisela a quien le tocó en suerte Francisco de las Heras, el secretario de la condesa de Paredes ${ }^{92}$.

48:100, "es común de dos lo virgen". Dicen S\&R: "verso difícil de explicar". En el diccionario académico, virgen va seguido de la abreviatura com., que quiere decir 'sustantivo común de dos' (la/ el virgen, como también la/ el reo, la/ el testigo). Supongo que por eso MP no puso ninguna nota.

146:13-14, "[es mejor] consumir vanidades de la vida / que consumir la vida en vanidades". Nota de S\&R: el primer consumirsignifica 'educir' (?) o 'extinguir', y el segundo 'dedicar'. Yo pienso que los dos significan una sola cosa: 'gastar'. Cf. la Carta alpadre Núñez, líneas 189-194: 'Hay monjas que gastan el tiempo en murmurar y disparatar; yo lo gasto en estudiar'.

En el admirable soneto 195, que es la dedicatoria de la Inundación castálida (y que, gracias a la "nueva clasificación" de S\&R, ocupa en esta edición el núm. 1 que le es debido), hay una nota en que S\&R dicen que el editor de la Inundación "fue

92 Los wv. 15-16 dicen: "y salir de veinticinco / aunque salgamos de ochenta". MP completa el dicho: salir de veinticinco alfileres 'con el más primoroso atavio'; en cuanto a salir de ochenta, vacila entre dos explicaciones: quizá sea satírico (viejas que quieren parecer mozas), quizá alusión "a que el año del que salían fuese el de 1680", que es lo que aceptan S\&R, según los cuales en el v. 16 "se menciona el año 1680 ". Pero esto no puede ser. El 1ำ de enero de 1681 hacía apenas un mes de la entrada de los virreyes, y el romance tiene que ser de la época en que sor Juana estaba ya en asidua relación con la corte virreinal. (Lo habrá hecho a petición de la condesa, o del secretario, o de la propia damisela, la cual, naturalmente, debe haber sido la más aplaudida.) A mí me parece evidente la otra explicación: sor Juana, por boca de la anónima damisela, hace un chiste sobre las mujeres que nunca dejan de emperifollarse, aunque tengan más de 80 años (cf. Quevedo, passim, por ejemplo el soneto "Vida fiambre, cuerpo de anascote..."). No tiene sentido 'aunque es $1^{\circ}$ de enero de 1681 , nos ataviamos primorosamente'. 
probablemente fray Luis Tineo", para lo cual se apoyan en "la tesis de Eguía-Lis". Esto debe ser un lapsus, pues Eguía-Lis, La prisa de los traslados, op. cit., pp. 74-75, dice lo mismo que yo dije en 1980 ("Para leer la Fama...", NRFH, 29, p. 466): "el «anónimo» prologuista y autor de los epígrafes [es] don Francisco de las Heras, secretario de la ex-virreina".

200:2: "a Arquimédes, artífice famoso". La nota de S\&R: "Arquimédes, palabra acentuada expresamente llana por la rima”, no viene al caso, pues Arquimédes no está en rima. Se acentúa así por la etimología: latín Archimédes. Cf. Aristídes, supra, p. 125, nota 60.

Ni MP ni S\&R explican el v. 14 del soneto 210, "abrir los ojos y cerrar la boca". Es retruécano de lo que se le dice a un niño pequeño para sorprenderlo con una golosina: "Abre la boca y cierra los ojos".

S\&R imprimen así el v. 58 del Sueño: "máximas negras, longas entonando", y dicen que las máximas son "cierto tipo de nota musical que era o negra o blanca". No creo que sea así, e insisto en lo que digo en mis "Notas", $N R F H, 43$, p. 384. Las notas "máximas" son siempre blancas y cuadrangulares (el doble de largas que las "longas"). Si tengo razón, hay que poner coma en máximas. - Añado una observación muy marginal acerca del Sueño. Dicen S\&R: "El mejor resumen de este poema, como proveniente de la misma monja, nos lo dio el padre Calleja": "Siendo de noche, me dormí; soñé que...", etc. Yo no creo que Calleja, entusiasta admirador del Sueño, haya necesitado ayuda de la autora para entenderlo. Es él quien le ofrece al lector ese resumen para ponderar la estrechez del "campo" argumental de tan exuberante poema.

Los empeños de una casa, I, 824: "de tus rayos salamandra". Nota de S\&R: "Se decía que el fuego atraía a la salamandra". Más exactamente: se decía que el fuego era el elemento en que vivían las salamandras (Quevedo: "Está la ave en el aire con sosiego, / en la agua el pez, la salamandra en fuego...").

Saínete II de Los empeños, vv. 134-137: "Gachupines parecen / recién venidos, / porque todo el teatro / se hunde a silbos". Según Salceda, "aqui se alude al sonido fuertemente silbante que dan a la letra ese los peninsulares"; S\&R dicen también: gachupines son "los españoles, cuyas eses y cetas se notaban como sibilantes diferentes". La explicación me parece mala. Los españoles, "recién venidos" o no (y entonces lo mismo que hoy), pronuncian las sibilantes de manera distinta que nosotros, pero esto, 
ciertamente, no basta para hundir un teatro a silbos. Se trata de una verdadera rechifla organizada por los bromistas Arias y Muñiz contra el pobre Acevedo. Con el recuerdo aún fresco del buen teatro de Madrid, los gachupines "recién venidos" no tolerarían una comedia tan mala como esta de Acevedo, incomparable con "una de Calderón, Moreto o Rojas".

Respuesta a sor Filotea: "En esto sí confieso que ha sido inexplicable mi trabajo". Nota de S\&R: inexplicable. "interminable'. Para mí, no significa otra cosa que 'imposible de explicar': sólo sor Juana sabe el trabajo que le ha costado ser lo que es.

Antonio Alatorre El Colegio de México 